\title{
A Review of the Biology and Conservation of the Cope's Giant Salamander, Dicamptodon copei Nussbaum, 1970 (Amphibia: Caudata: Dicamptodontidae) in the Pacific Northwestern Region of the USA ${ }^{1}$
}

\author{
Alex D. Foster ${ }^{2}$, Deanna H. Olson ${ }^{3}$, and Lawrence L. C. Jones ${ }^{4}$
}

\begin{abstract}
The Cope's Giant Salamander Dicamptodon copei is a stream dwelling amphibian reliant on cool streams, native to forested areas primarily west of the crest of the Cascade Range in the Pacific Northwest region, USA. Unlike other members of the genus, adult $D$. copei are most often found in a paedomorphic form, and rarely transforms to a terrestrial stage. As a result, they are dispersal-limited, which may affect gene flow between watersheds. Land-use activities that alter stream and riparian temperatures, substrates, and stream flow patterns can negatively affect the salamander. Forest management and associated road construction are the most pervasive land-use activities across the species range, and can contribute to habitat alterations that may impede dispersal, increase stream siltation, and increase stream temperatures. The effects of these land-use activities, in combination with projected climate change scenarios are largely unknown for the species. This biological review combines the most up-to-date information about the species, its range, life history, habitats, and potential threats, and describes conditions and land management approaches for supporting long-term viable populations.
\end{abstract}

Key Words: Amphibia, aquatic, ecology, biodiversity, climate, conservation status, Cope's Giant Salamander, Dicamptodon copei, dispersal, Pacific Northwest region (USA), population

For a quarter of a century, rapid and poorly explained declines in amphibian populations have been taking place globally (Blaustein and Wake 1990, Olson and Chestnut 2014), and are now recognized as part of a world biodiversity crisis (Stuart et al. 2004, Lannoo 2005, Wake and Vredenburg 2008, World Wildlife Fund 2014). Amphibians with small geographic ranges and relatively large body sizes appear to be associated with a higher likelihood of population decline (Sodhi et al. 2008). The Cope's Giant Salamander Dicamptodon copei occurs primarily in a narrow band of latitude and longitude in western Oregon and Washington, in the Pacific Northwest region of the U.S.A. (Figure 1).

\footnotetext{
${ }^{1}$ Submitted on October 15, 2014. Accepted on November 7, 2014. Last revisions received on December 29, 2014.

${ }^{2}$ United States Department of Agriculture, Forest Service, Pacific Northwest Research Station, 3625 $93^{\text {rd }}$ Avenue SW, Olympia, Washington 98512 USA. E-mail: alexfoster@fs.fed.us

${ }^{3}$ United States Department of Agriculture, Forest Service, Pacific Northwest Research Station, 3200 SW Jefferson Way, Corvallis, OR 97331 USA E-mail: dedeolson@fs.fed.us

${ }^{4}$ United States Department of Agriculture. Forest Service, Pacific Northwest Research Station, 3625 $93^{\text {rd }}$ Avenue SW, Olympia, Washington 98512 USA. Current address: Southwest Reptile Research Collective, Tucson, Arizona, USA. E-mail: gilaman@comcast.net
}

DOI: 10.9784/LEB2(4)Foster.01

Electronically available on January 10, 2015. Mailed on January 10, 2015. 


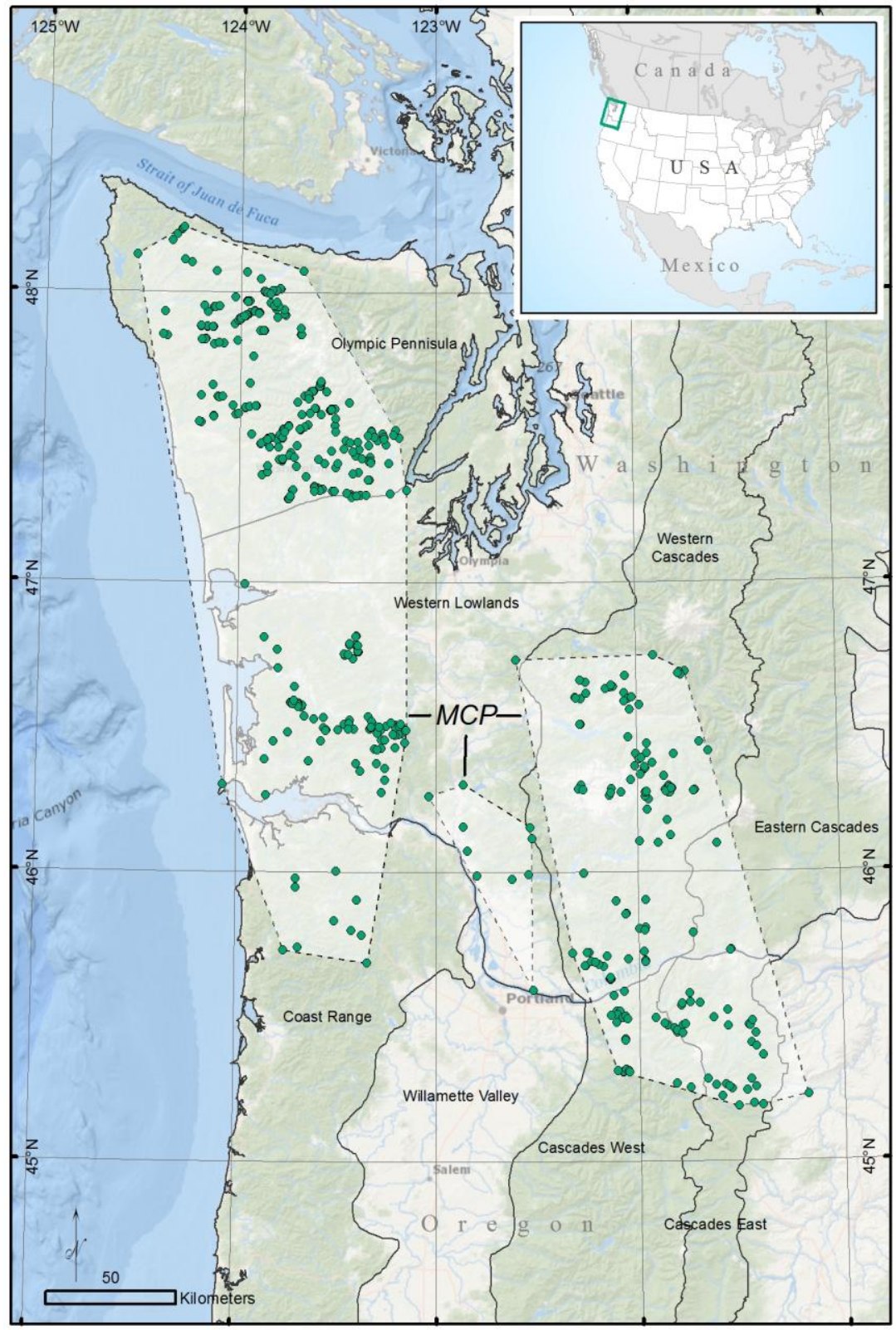

Figure 1. Known site records depicting the range of the Cope's Giant Salamander, Dicamptodon copei. Minimum convex polygons (MCP) of three areas of the range are indicated (-, with 408 records in the coastal area, 164 records in the Cascade Range area, and 10 records in between). 
Unlike other members of the genus Dicamptodon, D. copei rarely transforms to an adult terrestrial form (Nussbaum, 1970, 1976), thus its life cycle is primarily aquatic, with greater habitat specificity than other members of the genus.

The International Union for Conservation of Nature (IUCN) lists the species as least concern, based on its range and presumed large population, and considers it as locally threatened by land-use such as logging (Hammerson 2004). Regional assessments highlight the availability of habitat and the species' sensitivity to disturbance (Foster and Olson 2014). For example, although there is no official status listing by the U.S. Fish and Wildlife Service, in Oregon it is recognized as a sensitive species by various federal agencies and by the state of Oregon because of its restricted range and its potential susceptibility to land management activities (ORBIC 2013). In Washington, where the species is more common, it is recognized as a state-monitored species due to one or more of these factors: it was previously classified as sensitive; it requires habitat that is of limited availability; and it is an indicator of environmental quality (WNHP 2013).

Since the IUCN assessment, genetic research has revealed that this species is dispersal-limited, showing significant population isolation by distance (Steele et al. 2009). This suggests a heightened susceptibility to environmental change from habitat fragmentation and range contractions that may result from a combination of disturbances common across its range, such as logging and roads. Future climate change scenarios may also exacerbate those effects (Trumbo et al. 2013). With regard to climate change, the IUCN status assessment generally does not account for slow-acting and synergistic processes that can affect stream flow, water temperature, spread of disease, and habitat loss for amphibians (Collins 2010, Ryan et al. 2014, Keith et al. 2014).

Overall, D. copei is an understudied amphibian species native to the temperate rainforests of the Pacific Northwest, with relatively little information published about its distribution, life history, trophic interactions, and responses to stress. Here we review and integrate available information on this species, with new understandings of its distribution and ecology, providing a framework for development of effective conservation approaches with the overarching goal of contributing to the long-term persistence of the species.

\section{Methods}

We provide a synthesis of all published accounts, reports, locality data from individuals and databases, expert opinion, together with some unpublished information, each noted as appropriate. While the synthesis focuses on biological and ecological information for $D$. copei, information for other species of Dicamptodon is also included to describe general characteristics of the genus.

There has been no systematic sampling for D. copei across Oregon and Washington, thus the known distribution is biased by an accumulation of 
opportunistic sampling events. We compiled site records from state and federal databases, individual researchers, and museum records. We acknowledge the collation of such irregularly collected data may bias the portrayal of the species' distribution, and some occupied areas could still be unsampled. Hence, we qualitatively rated the confidence of species identification and site location information and only data we deemed of higher quality was used to create the range map. We found many site records were duplicates from identical locations, so we consolidated records from the same exact coordinates, thus collapsing our site records into a more accurate composite of sites. We do not define "site" beyond a discrete coordinate, and we do not address the spatial scale that might relate to a sub-population. Movements of D. copei may occur in-stream, along the aquatic network, or overland, but little is known about the extent of such dispersal. Nevertheless, watershed boundaries are useful to consider for occupancy patterns of highly aquatic species such as D. copei, so we also counted and mapped the number of drainage basins that had at least one site record.

\section{Results and Discussion}

\section{Systematics}

The Pacific giant salamanders are members of the genus Dicamptodon. The genus contains four species, all of which are endemic to the Pacific Northwest. The genus has been variously classified in the amphibian families Ambystomatidae and Dicamptodontidae, both of which have relatively robust body forms and complex life histories. For example, the Cope's Giant Salamander, Dicamptodon copei is almost exclusively aquatic throughout its life, but terrestrial forms have been occasionally observed near streams. In general, along with some Ambystoma salamanders, the Pacific giant salamanders include the largest terrestrial-occurring salamanders on Earth. The Coastal Giant Salamander, Dicamptodon tenebrosus (Baird and Girard, 1852) may reach $330 \mathrm{~mm}$ in total length as a terrestrial adult, and $355 \mathrm{~mm}$ as an aquatic paedomorph - a sexually mature adult with juvenile morphological characteristics (Welsh 2005). Dicamptodon salamanders have characteristic anatomical traits such as the presence of the lacrimal bone in the skull and vomerine teeth that have a distinct "M" shape (Nussbaum et al. 1983).

Initially, there was a single recognized species, the Pacific Giant Salamander Dicamptodon ensatus (Eschscholtz, 1833), with a broad range across the Pacific Northwest U.S. and Canada, from northwestern California to southwest British Columbia and east to Idaho. Nussbaum (1976) suggested that the Pacific Giant Salamander had three geographic populations occurring in northern California through western Oregon and Washington and in Idaho, whereas D. copei was geographically isolated in western Washington and extreme northwest Oregon. Nussbaum went on to suggest that ancestral 
Dicamptodon salamanders may have been found throughout much of the Pacific Northwest as far back as early the Miocene (20 million years ago), and that Pleistocene glaciation may have been a factor in the present range of D. copei, confining it largely to western Washington.

Genetic studies have since shown that the Pacific giant salamanders consist of four distinct species. The Coastal Giant Salamander D. tenebrosus has the broadest range along the Pacific coast and overlaps the ranges of both the California Giant Salamander Dicamptodon ensatus and D. copei. The Idaho Giant Salamander Dicamptodon aterrimus (Cope, 1867) is geographically separated from the other three species and is thought to be of an independent lineage (Daugherty et al. 1983, Good 1989). Comparison between the D. copei and D. tenebrosus shows that their DNA sequences have evolved independently (Daugherty et al. 1983, Brinkman et al. 2000). In general, Dicamptodon speciation is attributable to ancient geologic events, while more recent Pleistocene glaciation has shaped genetic variation and distributions within the four extant species (Steele et al. 2005). Dicamptodon copei also displays a high degree of population-level genetic structure, most likely from a combination of climatic events such as glaciation as Nussbaum (1976) suggested, orogenic (mountain building) activities of the Coast and Cascade Ranges, and because $D$. copei does not readily transform into a terrestrial adult. These factors affect overland dispersal and gene flow (Steele et al. 2005, 2009).

\section{Species Description}

Dicamptodon copei is the smallest of the four species of Dicamptodon, with a total length reaching $120 \mathrm{~mm}$ snout-to-vent (SVL) length, and reaching 200 $\mathrm{mm}$ total length (TL) in both its paedomorphic and terrestrial adult forms (Jones and Bury 2005). Dicamptodon tenebrosus is the only Dicamptodon to live sympatrically with $D$. copei where their ranges overlap in southwestern Washington, northwestern Oregon, and the Cascade Range. The two species do not co-occur in the Olympic Peninsula however, and recent genetic studies suggest the Willapa River in southwest Washington State as the northern boundary of D. tenebrosus (Spear et al. 2011). The two species of Dicamptodon are difficult to differentiate (Table 1, Figures 2 and 3), especially in their larval forms. 
Table 1. Comparison of morphological features of larvae and paedomorph Cope's and Coastal Giant Salamanders, Dicamptodon copei and D. tenebrosus (see Figure 2).

\begin{tabular}{|c|c|}
\hline $\begin{array}{l}\text { Cope's Giant Salamander, } \\
\text { Dicamptodon copei }\end{array}$ & $\begin{array}{l}\text { Coastal Giant Salamander, } D . \\
\text { tenebrosus }\end{array}$ \\
\hline $\begin{array}{l}\text { Head shape long and slender, about the } \\
\text { same width as body; more pronounced in } \\
\text { larger larvae and paedomorphs (Figure } \\
\text { 2A) }\end{array}$ & $\begin{array}{l}\text { Head shape short and wider than body; } \\
\text { more pronounced in larger larvae and } \\
\text { paedomorphs (Figure } 2 \mathrm{~F} \text { ) }\end{array}$ \\
\hline $\begin{array}{l}\text { Dark brown with distinctive } \\
\text { yellowish/tan patches in both larvae and } \\
\text { paedomorph (Figures } 2 \text { A-D) }\end{array}$ & $\begin{array}{l}\text { Medium to dark brown with no yellowish } \\
\text { patches, but may have speckling. Light } \\
\text { streaking often times in larvae or } \\
\text { mottling with little contrast (Figures } 2 \text { F-I) }\end{array}$ \\
\hline $\begin{array}{l}\text { Gill filaments usually shorter than stalks; } \\
\text { more pronounced in larger larvae and } \\
\text { paedomorphs (Figure } 2 \mathrm{~A} \text { ) }\end{array}$ & $\begin{array}{l}\text { Gill filaments usually longer than stalks } \\
\text { appearing more "bushy;" more } \\
\text { pronounced in larger larvae and } \\
\text { paedomorphs (Figure } 2 \mathrm{~F} \text { ) }\end{array}$ \\
\hline $\begin{array}{l}\text { Little dark mottling on tail in larvae, tail } \\
\text { is not much higher than body (Figure } \\
\text { 2E). Tail fin always starts posterior to the } \\
\text { vent }\end{array}$ & $\begin{array}{l}\text { More dark mottling on tail, sometimes } \\
\text { with black tail tip in larvae, tail higher } \\
\text { than body (Figure } 2 \mathrm{~J} \text { ). Tail fin starts } \\
\text { opposite to or anterior of the vent }\end{array}$ \\
\hline $\begin{array}{l}\text { Toe tips do not or barely touch when } \\
\text { adpressed against body front to back; } \\
\text { more pronounced in larger larvae and } \\
\text { paedomorphs }\end{array}$ & $\begin{array}{l}\text { Toe tips touch and often overlap; more } \\
\text { pronounced in larger larvae and } \\
\text { paedomorphs }\end{array}$ \\
\hline $\begin{array}{l}\text { Dark gray ventral pigmentation in larvae/ } \\
\text { paedomorph }>50 \mathrm{~mm} \text { in length; however } \\
\text { small larvae same as } D \text {. tenebrosus }\end{array}$ & $\begin{array}{l}\text { Whitish to cream ventral area; less } \\
\text { pigmentation }\end{array}$ \\
\hline
\end{tabular}




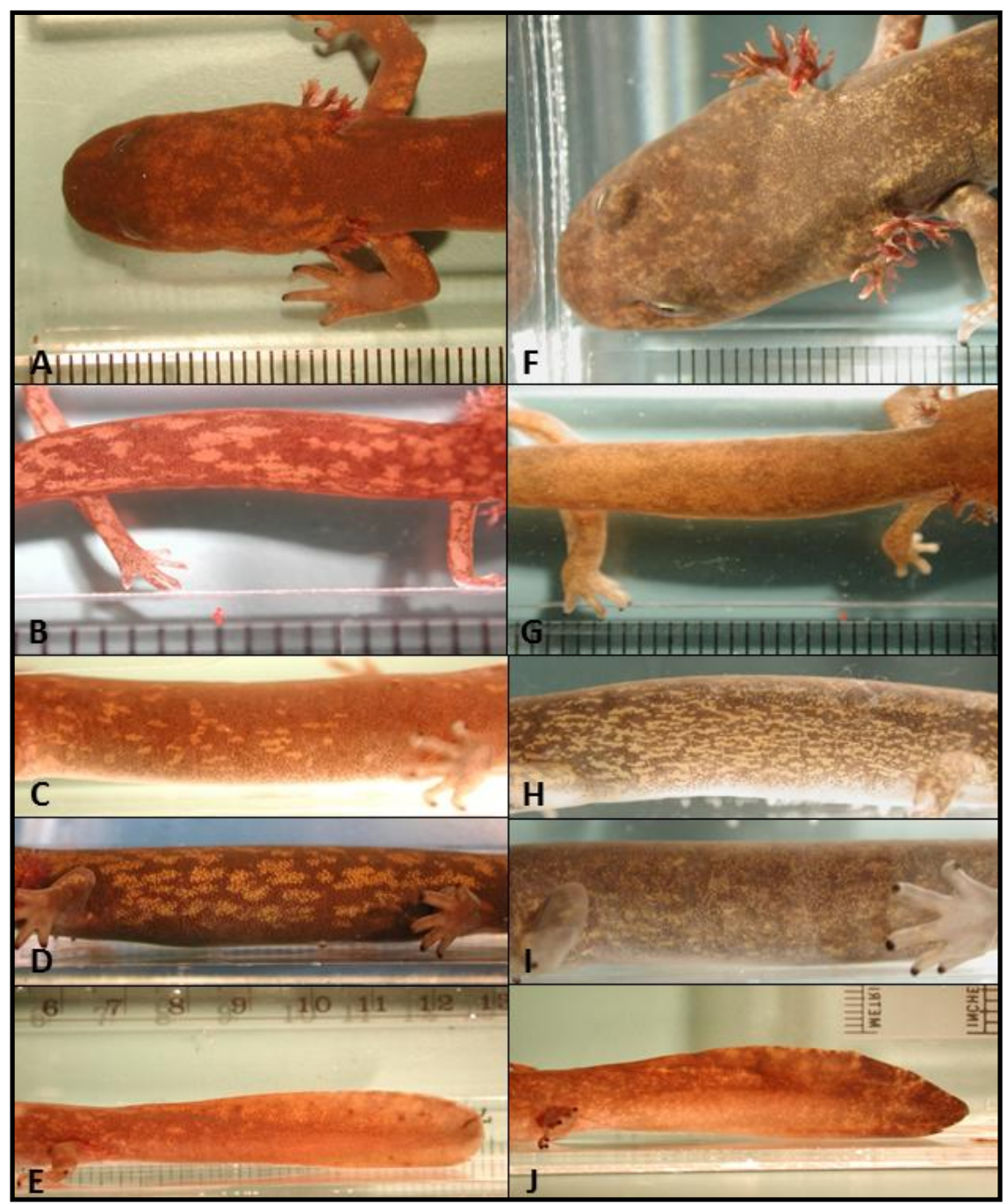

Figure 2. Comparison between Cope's (left A-E), Dicamptodon copei, and Coastal (right F-J) Giant Salamander, D. tenebrosus, larvae and paedomorphs (see Table 1; from Jones and Raphael 2001). Note: pattern and texture is accentuated under laboratory lighting and color is somewhat distorted. 


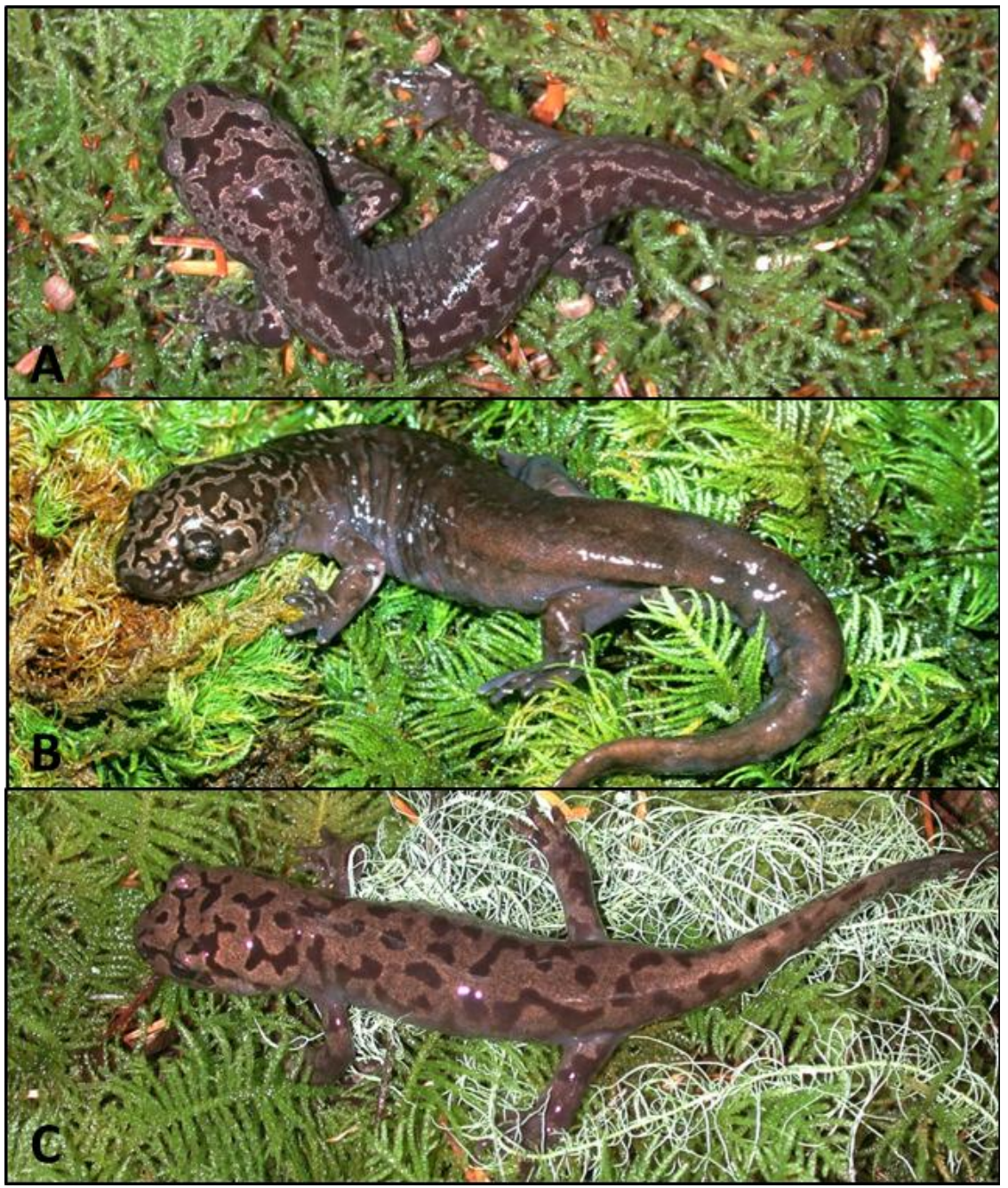

Figure 3. Morphometric comparison between Cope's Giant Salamander (top A; middle B); small size, marbling pattern always present but can be restricted to the head in Cascade populations. Recently metamorphosed Coastal Giant Salamander (bottom C); larger size than the Cope's, marbling present but can be faded or absent entirely on older individuals. Photographs not to scale. Dicamptodon copei may reach $200 \mathrm{~mm}$ in total length while D. tenebrosus may reach $330 \mathrm{~mm}$. Courtesy of L. L. C. Jones (A and C) and Bill Leonard (B). 
Nussbaum (1970, 1976) distinguished the larval and paedomorphic Cope's Giant Salamander D. copei from the broad-ranging Pacific Giant Salamander (then known entirely as $D$. ensatus; inclusive of $D$. tenebrosus, D. aterrimus, and D. ensatus endemic to California) as having (1) more slender body proportions, (2) a smaller head, (3) a pattern that includes distinct yellowish to tan patches (xanthophores), (4) a smaller larval size at sexual maturity, (5) shorter limbs with toe tips that do not touch when adpressed, (6) a reduced number of maxillary and vomerine teeth, (7) reduced sensitivity to induce metamorphosis by exposing to a thyroid extract, (8) a darker venter in individuals > $50 \mathrm{~mm}$ in length, (9) a shorter and lower tail fin, and (10) fewer gill rakers per arch. Dicamptodon copei has lighter mottling on the tail, and the tail fin always starts posterior to the vent, whereas on D. tenebrosus the fin starts opposite to or anterior of the vent (Figures 2 and 4).

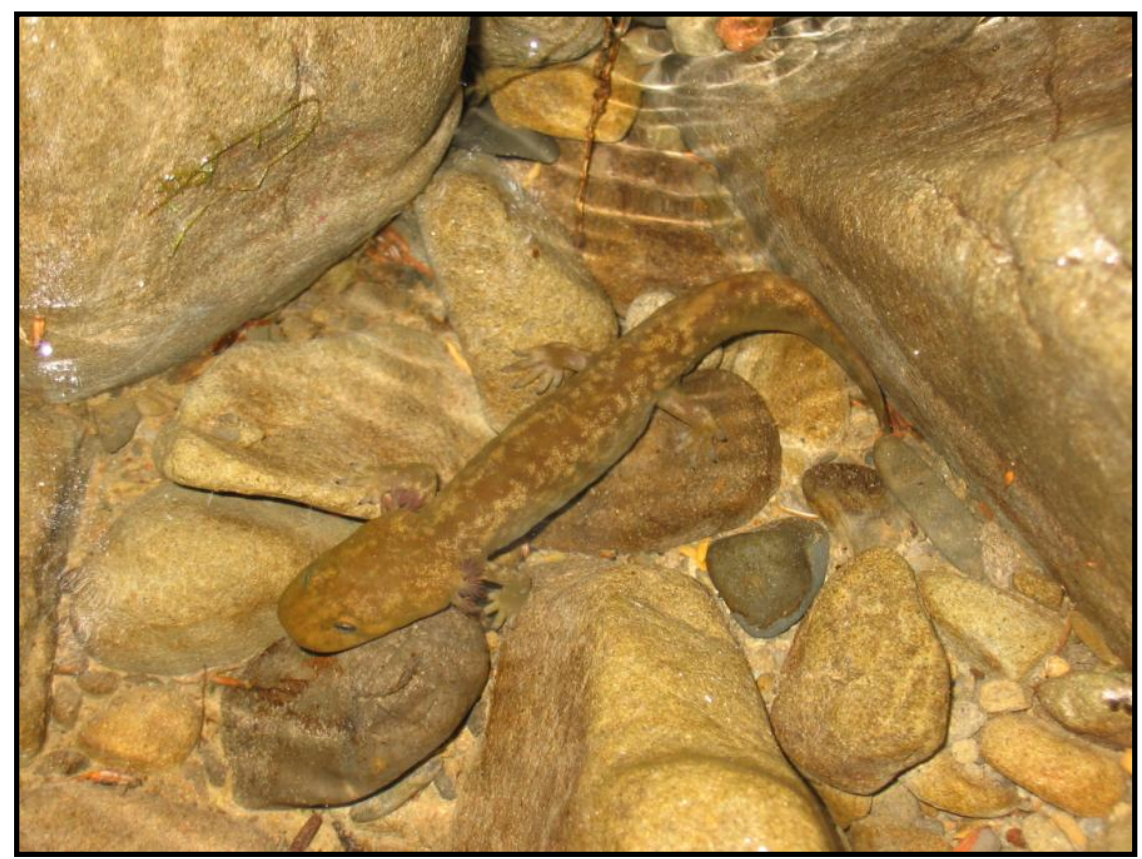

Figure 4. Cope's Giant Salamander, Dicamptodon copei. Adult paedomorphic form from the Olympic Peninsula, Washington State, USA. Courtesy of Chris Roberts.

As of the time of its publication, Loafman and Jones (1996) listed a total of six naturally occurring, metamorphosed D. copei; however Jones and Bury (2005) state that "metamorphosis in some populations is not as rare as previously believed." Additionally, Wagner (2014) suggested that D. copei is not entirely an obligate paedomorph, providing further evidence that transformed terrestrial adults are common at least in some populations. Key 
features that distinguish between $D$. copei and D. tenebrosus terrestrial adults are the larger size of $D$. tenebrosus and differences in marble patterning (Figure 3 ). At small sizes (i.e. recent metamorphs), D. tenebrosus may be similar in appearance and size to large, metamorphosed D. copei. Jones and Bury (2005) state that transformed $D$. cope $i$ have large eyes that are close together and occur as either marbled or "plain" phases. The plain phase has little marbling and the marbling is usually limited to the head (Figure 3; Jones and Bury 2005). Older D. tenebrosus terrestrial adults often lack marbled patterning but their large size (TL $>200 \mathrm{~mm}$ ) is a key feature to distinguish between species.

Although not quantified, regional trends in color-pattern variation have been observed in the larger larvae and paedomorphs of D. copei (Nussbaum 1969, 1976; Jones and Raphael 2001). For example, populations on the Olympic Peninsula have the classic pattern and color shown in Figures 2 and 4, whereas Cascade Range and Columbia River populations are more variable, with some individuals having few patches, and are overall darker in color than those in the Olympic Peninsula. Some populations in the Willapa Hills area of southwest Washington have intermediate characteristics between those of the Olympics and Cascades, suggesting the variations are related to hybridization with $D$. tenebrosus (Spear et al. 2011).

\section{Life History}

\section{Biology and Ecology}

Dicamptodon copei oviposition presumably occurs throughout the spring, summer, and fall months, perhaps with peaks in the spring and fall, based on ovarian egg development throughout the active season (Nussbaum 1969; Nussbaum et al. 1983). Females deposit eggs in clutches in hidden chambers under stones, undercut banks, and logs. Eggs are attached singly to the roof and sides of the chamber. The female remains in the nest chamber until the eggs hatch. Guarding females will sometimes bite or snap at an intruder, often another giant salamander attempting to feed on the eggs. Other giant salamander individuals are frequently found near the egg chambers, often with eggs in their stomachs and bite marks on their bodies. Only partial clutches were encountered, so egg predation appears to be high. Clutch size ranges from 25 to 115 eggs, averaging about 50 eggs. Deposited ova are white and $5.5 \mathrm{~mm}$ in diameter. In a laboratory setting at $8.0 \mathrm{C}, 240$ days elapsed from blastula to feeding (as with other Dicamptodon, pre-feeding larvae subsisting on yolk reserves after hatching). Hatchlings are about $20 \mathrm{~mm}$ and begin feeding at about $34 \mathrm{~mm}$ in total length. Larvae of both sexes mature at about the same size, $\sim 65$ to $77 \mathrm{~mm}$ total length.

In D. copei, occasional transformed terrestrial adults have been reported from Washington (Nussbaum 1976, Jones and Corn 1989; Loafman and Jones 1996, Jones and Bury 2005, Wagner 2014), but there have been no reports of oviposition by transformed individuals, or the appearance of gravid females. 
However, this may be an artifact of the rarity of transformed individuals. In addition, size at metamorphosis has not been reported, but naturally occurring metamorphs in some of the reports cited above ranged from 81-120 mm SVL; putative metamorphs were slightly larger (L. L. C. Jones, unpublished data).

For comparison, D. tenebrosus metamorphosis occurs between 92 and 160 $\mathrm{mm}$ SVL, thus while there is a much larger maximum adult size in $D$. tenebrosus when compared to D. copei, size of small metamorphic individuals of D. tenebrosus overlaps that of D. copei (Jones and Bury 2005, Welsh 2005). Also, D. tenebrosus can attain the largest size of any Dicamptodon, reaching $190 \mathrm{~mm} \mathrm{SVL}$ and $330 \mathrm{~mm}$ total length; the largest paedomorph measured was $355 \mathrm{~mm}$ total length (Welsh 2005). The California Giant Salamander Dicamptodon ensatus metamorphoses at about $115 \mathrm{~mm}$ SVL, but can reach 304 $\mathrm{mm}$ total length as an adult (Fellers and Kuchta 2005). While D. copei is generally considered a near-obligate paedomorphic species, all others are considered to be facultative metamorphic, although $D$. ensatus is less likely to remain paedomorphic than the other species in most of its range (Fellers and Kuchta, 2005). Nussbaum (1976) suggested that metamorphosis of the former broad-ranging "Pacific Giant Salamander" (D. aterrimus, D. ensatus, and $D$. tenebrosus, combined) may be related to stream flow, with intermittent streams having a higher percentage of transformed individuals. Somewhat related, experiments to induce metamorphosis by decreasing water level and raising water temperature in laboratory aquaria were unsuccessful for both $D$. copei and D. tenebrosus (Wagner 2014).

\section{Activity Patterns and Movements}

Little information exists for $D$. copei activities and movements, but given the relatively small size and aquatic lifestyle of $D$. copei, it should not be implied the natural history traits of the other species of Dicamptodon necessarily reflect those of D. copei. Dicamptodon tenebrosus and D. copei larvae, paedomorphs, and adults are most active at night (Parker 1994, Johnston 1998, Johnston and Frid 2002, Jones and Bury 2005). Movements of marked larval $D$. tenebrosus in small streams showed they covered short distances, averaging 3.2 $\mathrm{m}($ maximum $=51 \mathrm{~m})$ during summer and $15 \mathrm{~m}$ in winter $($ maximum $=89 \mathrm{~m}$; Sagar, 2004). Movement was predominately upstream in summer and downstream in winter; annual movement of D. tenebrosus larvae was $60 \%$ downstream and $40 \%$ upstream, and was not associated with larvae size (Sagar 2004). Road culverts also had an effect on larval movement, with less upstream movement in pipe culverts than in open-bottom arched culverts that retained the natural streambed substrate and roughness (Sagar 2004). Using perforated PVC pipes to sample hyporheic zones of streams in summer to fall low-flow conditions, Feral et al. (2005) captured seven D. tenebrosus in traps sampling $30-60 \mathrm{~cm}$ below the substrate surface. This report of subsurface occurrences 
documents the likely vertical migration of individuals, and the three-dimensional use of the streambed by Dicamptodon.

A telemetry study showed adult terrestrial $D$. tenebrosus spending most of their time in refugia (e.g. burrows and rotten logs), yet making occasional longdistance forays over a short time-frame (Johnston 1998, Johnston and Frid 2002). They moved a maximum distance of $67 \mathrm{~m}$ and cumulative distance of $310 \mathrm{~m}$ in 48 hours, and also stayed relatively close to streams (e.g. three animals ventured 19, 22, and $66 \mathrm{~m}$ away from streams during radio-tracking: Johnston 1998, Johnston and Frid 2002). Johnston and Frid (2002) found D. tenebrosus closer to streams in clear-cuts as compared to forested stands, which may have been related to microclimates of those areas. In addition, they estimated the home range of a single animal to be $935 \mathrm{~m}^{2}$, suggesting that a relatively large area could be traversed by a single individual. Observations of $D$. tenebrosus farther from streams are also documented by pitfall trap studies in western Oregon (to $135 \mathrm{~m}$ : McComb et al. 1993a to $200 \mathrm{~m}$ : Gomez and Anthony 1996 to 400 m: McComb et al. 1993b).

Genetic studies similarly support larger-scale movements of $D$. tenebrosus and influences of climate and landscape factors on its dispersal. Dudaniec et al. (2012) examined northern "peripheral" populations of D. tenebrosus in British Columbia, Canada, in comparison to population "core" regions in Washington state, and found genetic support consistent with a post-glacial northward range expansion of the species. Their data suggest that the northernmost populations are more isolated, hence with a naturally fragmented population structure; consequently, they suggest that these populations may be more sensitive to additional changes in habitat conditions. In their analyses of landscape correlates of population genetic structure, Dudaniec et al. (2012) found that slope and elevation had the greatest influence on genetic structure in the northernmost peripheral sites examined, whereas among core populations in Washington, genetic structure was best explained by flat topographies and the length of growing season. These results suggest that both landscape and climate features affect dispersal, and may affect populations differently across their range. Steele (2006) examined the genetic structure of D. copei and D. tenebrosus. He found that the genetic structure in $D$. copei supported a dispersal-limited species with greater population isolation, in comparison to the broader-ranging $D$. tenebrosus. This implies that there is limited movement of $D$. copei across landscapes or watersheds.

\section{Food Habits}

The bulk of $D$. copei diet consists of larval aquatic insects, with additional components including fish eggs, small fish, Coastal Tailed Frog, Ascaphus truei (Stejneger, 1899) tadpoles, and small larvae and eggs of their own species and of D. tenebrosus (Nussbaum et al. 1983). 
Both $D$. copei and D. tenebrosus frequently occur in streams inhabited by fish. Both Dicamptodon species and Rainbow Trout, Onchorynchus mykiss (Gibbons, 1855) were both found to be opportunistic feeders on aquatic insects, whereas Slender Sculpin, Cottus tennuis (Evirmann and Mek, 1898) were more selective of their prey (Antonelli et al. 1972). Like the sculpin, both species of Dicamptodon were found to feed primarily from the benthos. The bulk of aquatic insects found in the gut of both species of Dicamptodon were ephemeropterans, followed by plecopterans and trichopterans. In addition, in the Willapa Hills of southwest Washington, a D. copei paedomorph was observed with the hind limb of a terrestrial Camel Cricket, Tropidischia xanthostoma (Scudder, 1861) hanging from its mouth (Price et al. 2006), suggesting that in pursuit of terrestrial prey, paedomorphs may occasionally move away from water.

In D. tenebrosus, diet appears to vary geographically. Parker (1994) found that both aquatic and terrestrial insects that fall into the water were primary dietary components, with Ephemeroptera nymphs being the most frequently consumed prey. A study in a 4th-order stream (Strahler 1957) in the Oregon Cascade Range examined the stomach contents of 39 D. tenebrosus with a mean SVL length of $113 \mathrm{~mm}$ (Esselstyn and Wildman 1997). The mayfly, Baetis spp., was the most frequent item of animals captured from an upstream reach, whereas the aquatic snail Juga sp. was the most common prey type of animals in the downstream reach; crayfish Pacifastacus sp. were commonly found in stomachs of animals in both areas. Small quantities of a broad array of taxa were also found in salamander stomachs, including other Ephemeroptera, Trichoptera, Plecoptera, Coleoptera, Diptera, Hydracarina, Decapoda, Cottidae, and terrestrial insects. Graff (2006) found that food resources were not strongly partitioned between age classes in D. tenebrosus, and the most frequently consumed benthic macroinvertebrates included larval Diptera, Ephemeroptera, Plecoptera, and Trichoptera. Larval D. tenebrosus were also found to be dietary generalists, consuming several types of invertebrates (Cudmore and Bury, 2014). D. tenebrosus larvae and paedomorphs readily consumed Coastal Tailed Frog larvae when placed in holding buckets during electrofishing surveys, and terrestrial adults have been observed consuming banana slugs Ariolimax sp. (D. H. Olson, pers. observ.) and small mammals (E. Forsman, pers. comm.). During an experimental study of predator-prey relationships, D. tenebrosus larvae readily consumed Dunn's Salamanders, Plethodon dunni (Bishop, 1934), but rejected Southern Torrent Salamanders, Rhyacotriton variegatus (Stebbins and Lowe, 1951) as apparently unpalatable (Rundio and Olson 2003).

\section{Range, Distribution and Abundance}

Dicamptodon copei ranges across two distinct ecoregions in western Washington and Oregon, occurring predominantly in the Coast Ranges and the west slope of the Cascade Range (Figure 1). In the Coast Ranges, it occurs from 
the northwestern corner of the Olympic Peninsula in Washington southward to the Nehalem River watershed in Oregon, and in the Cascade Range it occurs from the Nisqually River at Mount Rainier National Park, Washington, southward to the upper White River watershed just east of the Cascade crest (Bury et al. 2014) in Wasco County, Oregon. The species is absent in the Puget Sound lowlands, northeast corner (rain shadow area) of the Olympic Peninsula and the Willamette Valley lowlands and foothills in Oregon. Sporadic sites between the Coast Ranges and Cascade Range are known through Clark and Cowlitz counties in Washington.

We compiled 986 site records in Oregon and Washington, however many site records were duplicates from identical locations, representing either re-visits to the same site over time, duplicate entries of the same data among collated databases, or many individual animals detected from the same location during a single visit, with a single record entered into the database per animal. We consolidated site records from the same exact coordinates, and the number of sites collapsed by $60 \%$ to 582 . Confidence of both location accuracy and species identification at the 582 sites was rated high. The Oregon and Washington combined total range is about 3,198,367 ha, derived using the calculation of three minimum convex polygons of site records, excluding the unoccupied Puget Sound lowlands and Willamette Valley from the calculation (Figure 1). The three subunits consist of: coastal sites, 408 site records, range $=1,885,704$ ha; Cascades, 164 site records, range $=1,172,498$ ha; and in between these two ranges, 10 site records, range $=140,165$ ha. Some of the sites were in close proximity to each other along the same stream reach or within the same small drainage basin. There were 165 occupied 6th-field watersheds (hydrologic unit code 12, HUC12; Figure 5). The average watershed area was $90 \mathrm{~km}^{2}$, the minimum area was $26 \mathrm{~km}^{2}$ and maximum was $182 \mathrm{~km}^{2}$. In addition, sites ranged in elevation from $5 \mathrm{~m}$ in the Puget Sound (Western) Lowlands physiographic province of Washington to $1593 \mathrm{~m}$ in the Cascades East province. The average elevation was $475 \mathrm{~m}$ across the entire range, with higher-elevation sites tending to occur more in the Cascades provinces.

In Washington, D. copei is known from 11 counties (Clallam, Jefferson, Grays Harbor, Mason, Pacific, Wahkiakum, Cowlitz, Lewis, Clark, Skamania and Pierce), and in Oregon, it occurs in seven counties (Hood River, Wasco, Clackamas, Multnomah, Clatsop, Washington and Tillamook). Most sites that we compiled occurred on federal lands (372 of 582 [64 \%] site records), likely reflecting a bias of both survey locations and information that we were able to compile.

\section{Demography and Population Trends}

In general, aside from some unpublished data, little information exists about the age-size structure of $D$. copei populations. From earlier knowledge of the former broad-ranging species, the "Pacific Giant Salamander" (D. ensatus, 
inclusive of $D$. copei and D. tenebrosus); the structure of larval populations was known to vary greatly across its range (Nussbaum and Clothier 1973).

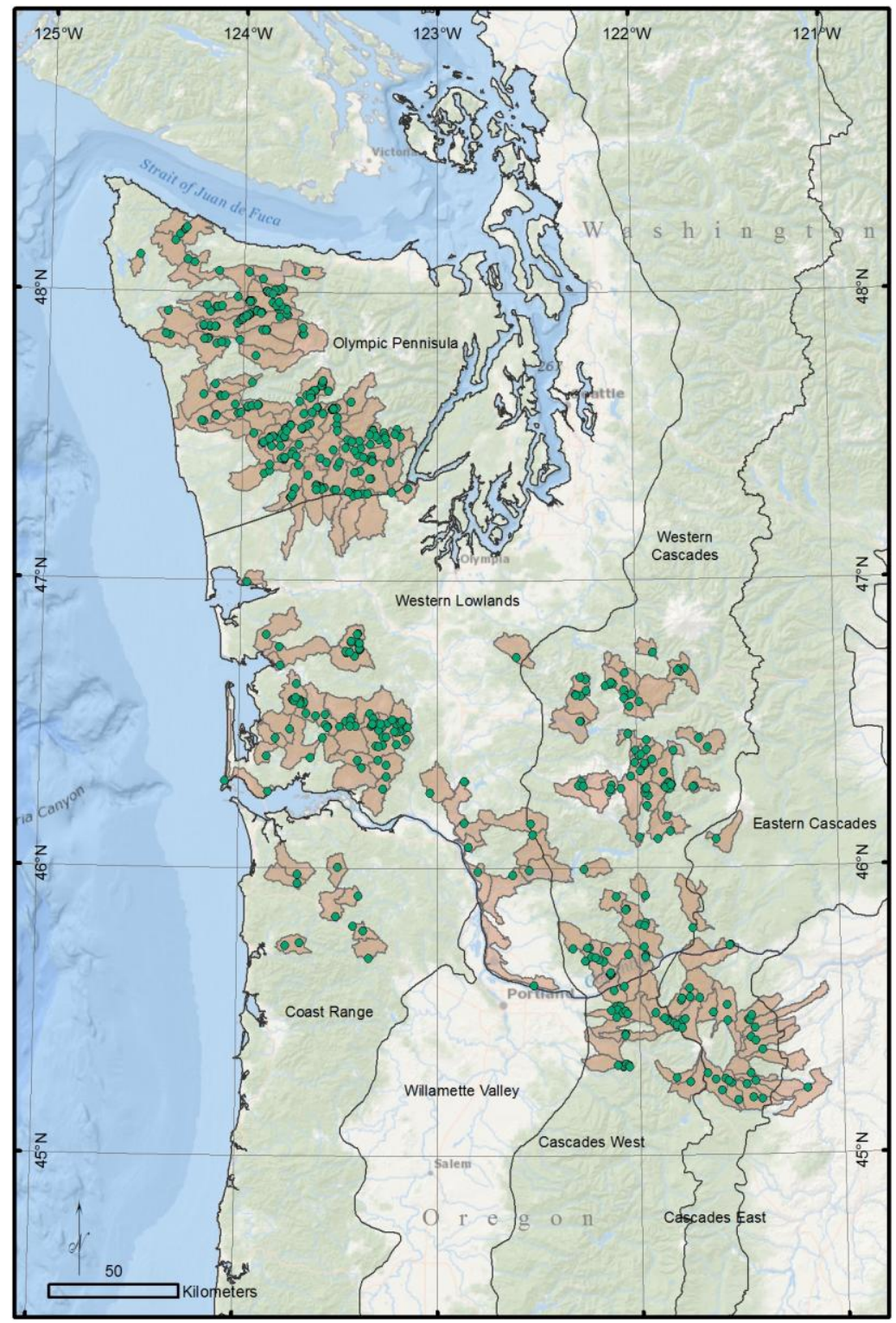

Figure 5. Sixth-field watersheds (hydrologic unit code 12, HUC12; $n=165$ ) with known site records of the Cope's Giant Salamander, Dicamptodon copei. Average watershed area $=90 \mathrm{~km}^{2}$. 
More recent surveys in the Olympic Peninsula specific to D. copei suggest some age-size segregation. For example, on twenty-eight small- to intermediatesized streams ( 2 to $6 \mathrm{~m}$ wetted width) surveyed during summer (June through August) 1996 through 1999, larval and paedomorphic D. copei had a distinct bimodal distribution showing two size-classes (age categories), with average total lengths of $53 \mathrm{~mm}$ and $143 \mathrm{~mm}$ respectively (A. D. Foster, unpublished data). Surveys have assessed $D$. tenebrosus population size distributions in Oregon, and there appear to be differences in age-size structures of populations with location, habitat type, growth rate, and the time of metamorphosis. In some locations, two size-classes of $D$. tenebrosus were present during spring and early summer. For example, size-class structure of $D$. tenebrosus in small streams $(<3$ $\mathrm{m}$ wide at low flow) of the Oregon Coast Range showed that populations were made up mostly of first-year larvae, with few older larvae or paedomorphs (SVL length range: 30-100 mm; Sagar 2004; Sagar et al. 2007). In addition, summer survival for first-year larvae was lower than for 2nd- and 3rd-year larvae. These studies suggest that older larvae may be better able to secure refugia, and thus evade detection and predators. Dicamptodon tenebrosus were the dominant vertebrate in another study of headwater streams in western Oregon (Olson and Weaver 2007, Olson et al. 2013), and total lengths of individuals in those streams (1-4 m wide) ranged from 25-285 mm (SVL lengths ranged 12-180 $\mathrm{mm}$ ), without clear delineation of age classes (D.H. Olson, unpublished data). Downstream of one of those headwater study sites, in a larger stream reach $(\sim 10$ $\mathrm{m}$ wide during low flow) of Schooner Creek in the Oregon Coast Range, instream $D$. tenebrosus ranged from $\sim 32-265 \mathrm{~mm}$ in total length, again without distinct age classes present (D. H. Olson, unpublished data). Age class segregation should be viewed cautiously since all Dicamptodon are presumed to be senescent, and age-class differentiation probably is not shown by size-class modality after the first 2-3 years.

Genetic studies have suggested that the general trend toward obligate paedomorphism as a factor in D. copei distribution. Phylogenetic patterns of population structure in terms of genetic fidelity between sympatric populations of $D$. tenebrosus and $D$. copei indicated that the metamorphosing $D$. tenebrosus displayed a more continuous population, whereas the non-metamorphosing $D$. copei exhibited a larger degree of population structure (Steele 2006). These results help explain the large post-glacial distribution of D. tenebrosus, facilitated by its higher dispersal ability, as compared to the apparently more fragmented occurrences and smaller range of $D$. copei. It was further shown that stream and overland distance were correlated with genetic distance for $D$. copei but not so for $D$. tenebrosus (Steele et al. 2009). This suggests that $D$. tenebrosus is dispersing among localities regardless of physical or topographic features, and is doing so to a degree sufficient to cause genetic mixing, but $D$. copei is not, thus its populations have heightened genetic isolation. However, some long distance $(13 \mathrm{~km})$ dispersal has been noted in the Olympics (Spear et 
al. 2011). Interestingly, D. copei reach their highest population size in the Willapa Hills area of southwest Washington and the South Cascades of Washington and the lowest in the Olympics where populations are exclusively $D$. copei (Spear et al. 2011). The highest phylogenetic divergence among $D$. copei populations was the separation of several populations found along the Columbia River from other populations. These divergent populations are geographically restricted to several short tributaries that drain directly into the Columbia River and are not joined to the large interconnected network of headwater streams that run throughout the Coast and Cascade Ranges (Steele and Storfer 2007).

Research on long-term population trends for D. copei is lacking. However, in-stream densities have been documented by several studies. For example, in ten streams on the Olympic Peninsula, the average density was about $0.16 \mathrm{~m}^{2}$ from June through August (Adams and Bury 2002). Additionally, in four streams in the Willapa Hills of southwest Washington surveyed by electrofishing twice per year for three years (2004-2006), the densities across years averaged about $0.30 \mathrm{~m}^{2}$ in July and $0.17 \mathrm{~m}^{2}$ in September. The summer decline was probably due to a combination of larval mortality, emigration from the surveyed areas, or both (A. D. Foster, unpublished data). In addition, densities for both D. copei and D. tenebrosus were between $0.06-1.4 \mathrm{~m}^{2}$ and 0.06-2.5 $\mathrm{m}^{2}$, respectively, in headwater streams in the Cascade Range of southern Skamania County, Washington surveyed in June through August (Steele et al. 2002).

\section{Habitat}

Dicamptodon copei are found in small, rocky, and usually steep-gradient streams in conifer or mixed forests (Jones and Bury 2005, Corkran and Thoms 2006). They can be found under stones, slabs of bark, or other cover objects in streams, and are often found in pool habitats with slow water rather than fasterflowing riffles. In high-moisture conditions, they can be found crawling among rocks and vegetation along stream banks at night (Nussbaum et al. 1983). Down wood is sometimes associated with observations of this species. For example, in the Olympic National Park, D. copei abundance peaked when there was about $10 \%$ in-stream down wood cover (Adams and Bury 2002). They also found that abundance decreased with increasing canopy cover, started decreasing at elevations above $500 \mathrm{~m}$; was negatively associated with increasing stream width and was detected only in streams on unconsolidated surface geologies - those having plentiful boulder and cobble substrates. Dicamptodon copei and D. tenebrosus (combined) tended to be more common in basaltic substrates than marine sediments in coastal areas (Wilkins and Peterson 2000). High stream gradient was a predictor for the $D$. copei in headwater streams on the Olympic Peninsula (Raphael et al. 2002). Additionally, D. copei are also occasionally found in seepages and small wetland features in riparian areas, and can co-occur 
with torrent salamanders Rhyacotriton spp. in these habitats (Adams and Bury 2002, Jones and Bury 2005). They have been documented to occur in some mountain lakes (Nussbaum et al. 1983). In a study of eight streams with $D$. copei in the southern Washington Cascades, Bury et al. (1991) found D. copei were more often situated in pools than D. tenebrosus, and D. copei were found at a mean depth of $8 \mathrm{~cm}$, a little deeper than D. tenebrosus (5.4 for adults and 6.8 for larvae). In the same general area, Steele et al. (2002) found D. copei (in 24 streams) at an average depth of $4.3 \mathrm{~cm}$, and a similar depth for D. tenebrosus (at 18 streams). Cover object size for $D$. copei averaged $807 \mathrm{~cm}^{2}$, compared to $712 \mathrm{~cm}^{2}$ for larval D. tenebrosus and 2,410 $\mathrm{cm}^{2}$ for adults (Bury et al., 1991). Both $D$. copei and $D$. tenebrosus increased in abundance with increasing pool frequencies in combination with increasing large wood accumulations in adjacent riparian areas, but decreased with increasing accumulations of large (>60 cm diameter) wood in the stream channels (Wilkins and Peterson 2000).

In another study on the Olympic Peninsula, landscape-level factors had a greater influence on the presence of $D$. copei than in-stream habitat conditions (Bisson et al. 2002). No relationship was found between the density of D. copei and forest age in the riparian zone or the entire sub-watershed. There was reduced overall abundance in sub-watersheds with high road and drainage densities implying a potential sensitivity to chronic fine sediment input, yet density was the same in sub-watersheds with episodic coarse sediment introductions from landslides suggesting that the species may be resilient to these disturbances. Adaptation to mass wasting and associated coarse sediment influx was also suggested by Sepulveda and Lowe (2009) for the Idaho Giant Salamander Dicamptodon aterrimus.

There are several studies about habitat associations of $D$. tenebrosus that may provide further insights about $D$. copei. For example, pools with coarser substrates tended to have higher densities of D. tenebrosus in northern California (Parker 1991). Sagar (2004) also found coarser substrates showed a positive correlation to $D$. tenebrosus larval density and movement. The need for coarse substrates in stream channels should not be understated; cobble and larger rocks play a role in the reproductive activities of both species of giant salamanders as well as for clutch and ovipositioning (Wagner 2014). The abundance of $D$. tenebrosus increased with percent canopy cover of Douglas-fir, Pseudotsuga menziesii (Mirb. Franco), over the wetted width of the stream; cover, elevation, amount of down wood cover, and lithology type variables explained $96 \%$ of the variability of D. tenebrosus presence (Graff 2006). In Oregon headwater streams, D. tenebrosus were associated with perennial stream reaches, down wood, and stream gradient (Olson and Weaver 2007), and in unmanaged forest stands near Coos Bay, Oregon, the D. tenebrosus occurred in areas associated with fluvial and/or hillslope disturbance (Sheridan and Olson 2003). These studies suggest that down wood, coarse substrate, cover adjacent to the stream channel and geology may influence abundance of giant salamanders 
in the channel, and in the case of D. tenebrosus terrestrial adults in adjacent riparian areas.

\section{Other ecological considerations}

Interspecific interactions between $D$. copei and other species are not well studied. Relative to potential competition for food, there was considerable overlap in the diets of co-occurring Rainbow Trout, Slender Sculpin and both $D$. copei and D. tenebrosus (Antonelli et al. 1972). Trout were able to feed throughout the water column, but sculpin and the giant salamanders were primarily benthic feeders.

Interspecific interactions between Cutthroat Trout, Oncorhynchus clarki (Richardson, 1836) and D. copei may affect the salamander's population structure. For example, electrofishing surveys were conducted on four streams with $D$. copei for three consecutive years in the Willapa Hills of southwest Washington. When averaged across years, D. copei population density tended to be lower $\left(0.1 \mathrm{~m}^{2}\right)$ on two of the streams where Cutthroat Trout were present compared to streams with no fish $\left(0.3 \mathrm{~m}^{2}\right)$ (A. D. Foster, unpublished data). In Oregon, Cutthroat Trout and D. tenebrosus interactions were described as a complex combination of predation, competition, and facilitation, where trophic cascades subsequently exert potential top-down predator effects on several other taxa (Rundio 2002). D. tenebrosus larvae are palatable to Cutthroat Trout, and the salamander has behavioral defenses rather than chemical defenses against the trout. When cutthroat chemical cues were present, D. tenebrosus larvae took cover in refugia provided by down wood and coarse substrates (Rundio and Olson 2003). Dietary overlap at certain times of the year is high between $D$. copei and $D$. tenebrosus where they live in sympatry, however more recent results suggested that in response to presence of its congener, a shift in diet by either one or both species may occur to reduce competition for food resources (Steele and Brammer 2006).

Larval D. copei may be preyed upon by non-native Eastern Brook Trout, Salvelinus fontinalis (Mitchill, 1814) and possibly native Bull Trout, Salvelinus confluentus (Suckley, 1859). Both species of fish live in sympatry with D. copei at particular locations across the salamander's range, and both fish are opportunistic benthic feeders that may also compete with the salamanders for food resources. Dicamptodon copei also are preyed upon by gartersnakes, Thamnophis spp., adults and large larvae of D. tenebrosus, and Water Shrews, Sorex palustris (Richardson, 1828) (Nussbaum et al. 1983). Dicamptodon copei may be preyed upon by Raccoon, Procyon lotor (Linnaeus, 1758), Long-tailed Weasel, Mustela frenata (Lichtenstein, 1831), American Mink, Neovison vison (Schreber, 1777), and birds. Antagonistic behavior between a large $D$. tenebrosus and a gartersnake was recorded (Silvestri and Douglas 2006). However, because of $D$. copei's much smaller size compared to D. tenebrosus, it may be unable to fend off a larger snake's attack. Proof of snake predation was 
evident in a Common Gartersnake, Thamnophis sirtalis (Linnaeus, 1758) that regurgitated a metamorphosed D. copei (Loafman and Jones 1996).

\section{Threats and risk factors affecting the status of the species}

Although threats to $D$. copei are not well studied, primary suspected threats across the species' entire range include activities that may change habitat, microhabitat, and microclimate conditions. The main anthropogenic activities that may alter the species' habitat conditions include road construction and timber harvest. In particular, factors that alter microhabitats or create barriers to dispersal and gene flow likely affect this species. Microhabitat alterations of specific concern are decreased down wood recruitment, increased erosion and fine sediment deposition in streams, and increased water or soil temperatures, these alterations can be the result of timber harvest or from natural disturbances like landslides and forest fires. Additional concerns include disease, climate change, and chemical applications.

\section{Culverts and Roads}

Culverts and roads may affect microhabitat and both aquatic and terrestrial dispersal for this salamander. The chief concern with roads transecting aquatic habitats is their tendency to create dispersal barriers, and sedimentation (discussed below). The inability to disperse puts populations at risk because it limits gene flow and the ability to recolonize after disturbance (Jackson 2004). Maintenance of aquatic organism passage is a priority management concern, especially on federal lands (GAO 2001, Hoffman et al. 2012). Culverts at roadstream crossings have a long history as barriers to fish migration (Hoffman and Dunham 2007), and can be barriers to amphibian movement in forested landscapes as well (deMaynadier and Hunter 2000, Sagar 2004, Marsh et al. 2005, Andrews et al. 2008). Culverts may present barriers at the pipe outflow, where they may be "perched" with significant drops from the pipe edge to the stream surface. Dicamptodon salamanders are not known to "jump" like fish to move upstream across these small waterfalls. Culverts also may result in increased water velocity, which affects salamander movement because they are not capable of pushing upstream against strong currents. Furthermore, some types of culverts may have a surface that does not present any roughness characteristics like those of the natural streambed, which may be a significant factor for an animal that crawls for dispersal- the culvert bottom may be too smooth for the salamanders to maintain a grip even against relatively slow water velocities.

Whereas culvert and dispersal relationships specific to the D. copei are unknown, culverts have been documented to affect dispersal patterns of larval D. tenebrosus. For example, culvert presence was associated with fewer long distance movements (Sagar 2004). Culvert type also affected larval salamanders; density in arch (flat-bottom) culverts was no different from reference streams, 
but density was between 3.1 and 18.6 times greater in arch culverts than in pipe culverts. Although concerns about terrestrial connectivity for amphibians at road-stream crossings has been extensively documented (Andrews et al. 2008), it is unknown if $D$. cope $i$ can disperse out of the stream and cross the road prism, either at upland roads or at culverts.

\section{Timber Harvest}

Studies of effects of timber harvest on D. copei and D. tenebrosus show several patterns that are likely dependent upon the context of the study and the timber harvest practices addressed, as well as the geographic location of the study. Potential effects of some timber harvest activities on microhabitat features important for D. copei include direct stream-channel disturbances (e.g. historical practices of dragging logs across or along streams), loss of down wood, sedimentation embedding coarse substrates, and elevated water temperatures (see below). Historical clear-cut logging practices without riparian buffers were more likely to result in direct effects on aquatic amphibians and their habitats. Many studies do not report what mechanism or microhabitat factors may have been involved in the effects observed (e.g. substrate alteration or temperature change), but rather report broader-scale effects. Effects of harvest on animal occurrence and abundance, diversity, and biomass are not often differentiated in reports.

For example, in headwater streams draining from clear-cuts harvested 2634 years prior to amphibian surveys, there was a significant increase in the density of Pacific Giant Salamanders (most likely D. tenebrosus based on location) downstream of clear-cut areas (Biek et al. 2002). Comparing oldgrowth and logged redwood forests near Redwood National Park, California, the former broad-ranging Pacific Giant Salamander, D. ensatus, occurred on half of the old-growth sites, but none were found in logged areas harvested 6-7 years prior (Bury 1983). In contrast, there was no evidence found that clear-cut logging affected the density of larval $D$. tenebrosus two years following timber harvest in a coastal watershed in southwest Oregon (Leuthold et al. 2012). Bury et al. (1991) reported that there was no association of giant salamander abundance with forest type (old-growth, mature, young forest) on 59 streams sampled in Oregon and Washington. Corn and Bury (1989) found that $D$. tenebrosus in young managed forests were more numerous in higher stream gradients, but found no association with gradient in unharvested forests, suggesting that timber harvest may limit the salamanders to a narrower range of habitats than in unharvested forests. In addition, higher-gradient reaches likely flush fine sediments from substrates, and hence maintain interstitial refugia for salamanders. Clear-cutting also appears to have affected the behavior of metamorphosed $D$. tenebrosus in that they were more prone to stay close to streams, spend more time in underground refuges, and had smaller home ranges than salamanders in forested areas (Johnston and Frid 2002). Also, movement 
behavior was not different between riparian buffer strips and forested areas, but was different from clear-cuts. Genetic richness was positively correlated for $D$. tenebrosus with age of forest stands. Lower genetic variation and heterozygosity in recent clear-cuts suggested that clear-cut logging may be associated with local declines (Curtis and Taylor 2003).

In contrast, both $D$. copei and D. tenebrosus densities were greater in managed vs. unharvested second-growth forests in the Cascade ecoregion in southern Skamania County in Washington, where they reached their greatest densities in unbuffered streams (Steele et al. 2002). Pollett et al. (2010) had similar results for Dicamptodon salamanders as a group. Both publications suggested that the response was short-term, comparable to that also seen in salmonids, where canopy removal increases secondary production and quantities of macroinvertebrate prey. Lastly, thinning of young forest stands with riparian buffers appeared to have neutral or positive effects on giant salamanders in western Oregon. For example, there tended to be more D. tenebrosus detected after thinning in treatment reaches compared to unharvested reference reaches (two years after treatment: Olson and Rugger 2007; to 10 years after treatment: Olson et al. 2013), and there was no treatment effect after a second thinning harvest in the uplands with riparian buffers (Olson and Burton 2014). In addition, in an upland study, there was no effect on amphibians (including giant salamanders) from thinning in riparian buffers in the Oregon Coast Range (Kluber et al. 2008). However, Olson and Burton (2014) reported reduced densities of $D$. tenebrosus in small streams having thinned riparian buffers without a no-entry buffer zone; observations of harvest equipment tracks in some streams and the appearance of logs having been dragged through streams suggested that direct disturbances to stream channels might have led to the reduced salamander densities in this study.

\section{Chemical Applications}

Chemicals such as herbicides, pesticides, fungicides, fertilizers, and fire retardants may directly affect $D$. copei. Exposure could result from releases of these chemicals to waterways, as well as potential overspray effects on transformed adults within riparian areas. Specific chemical effects on this species are largely unknown yet the species may have similar sensitivities to acidification, ammonium, and certain pesticides such as organophosphates and organochlorine insecticides as were found for the aquatic larvae of anuran frogs (Fedorenkova et al. 2012). Chemical application on state and private forest lands commonly occurs across the species range. However, on federal land, threat of direct chemical applications is likely low, and the extent of effects of downstream flow of chemicals from upstream applications on non-federal lands is unknown. The threat of fire retardants and scope of their use on lands within the species range in Oregon and Washington is uncertain. Aerial drift of agricultural chemicals onto adjacent habitats may be an additional concern. 


\section{Fine Sediment}

Undisturbed populations of $D$. copei occur in areas subject to infrequent episodic mass-wasting events that introduce large pulses of both coarse and fine sediment to stream channels. However, in sub-watersheds with high road densities, chronic fine sediment influx to stream channels is a concern. Also, the increased frequency of mass wasting often triggered by roads or timber harvest on unstable slopes is a concern. Sedimentation can fill interstitial spaces in stream substrates, burying cobbles and boulders, and eliminating refugia, foraging and nesting habitat. For example, the abundance of $D$. cope $i$ was found to be reduced in sub-watersheds with high road and drainage densities, suggesting sensitivity to chronic fine sediment input to stream channels (Bisson et al. 2002). Also, relative abundances of lotic amphibians were significantly greater in late-seral forest streams compared with streams transecting mid-seral forests, and while water and air temperatures were similar in both forest types, the streams in mid-seral forests had greater amounts of fine sediments compared with the streams in late-seral forests (Ashton et al. 2006). Using substrate embeddedness as a surrogate for fine sediment loading, the probability of detection of $D$. tenebrosus was significantly reduced when embeddedness was $>75.5 \%$ (Welsh and Hodgson 2008). At the finest spatial scale (2-m sample unit), occurrence of all lotic amphibians was negatively associated with fine sediment (Stoddard and Hayes 2005).

In addition to road-related sediment sources, sediment loading in streams often corresponds to the type of timber-harvest treatment (Beschta, 1978). Correlations between increased sediment loads and clear-cutting were seen for one year following harvest for streams with a minimum of a $9 \mathrm{~m}$ no-entry zone along fishless streams, and a $15 \mathrm{~m}$ no-entry zone for fish-bearing stream reaches. However no significant correlation was found in areas with higher-retention treatments (Karwan et al. 2007). This tendency may contribute in part to the neutral effect on giant salamanders by variable-retention logging practices, as described previously. In contrast to chronic fine sediment sources over large areas, a large, episodic but concentrated disturbance such as a debris flow could extirpate a $D$. copei population in a given sub-watershed for a much longer period of time than observed in the rapid recolonization by salmonids, for example, after these types of disturbances (Swanson et al. 1998, Crisafulli et al. 2005, Cover et al. 2010; A. D. Foster, unpublished data).

\section{Water Temperature}

Both D. copei and D. tenebrosus often occur sympatrically with other amphibians that have at least partial aquatic life histories, including torrent salamanders, Rhyacotriton spp., and Coastal Tailed Frogs, Ascaphus truei. Dicamptodon tenebrosus have a slightly higher critical temperature threshold $\left(29.1^{\circ} \mathrm{C}\right)$ than torrent salamanders $\left(27.9^{\circ} \mathrm{C}\right)$, and roughly the same as tailed frogs $\left(29.6^{\circ} \mathrm{C}\right.$ ) (Bury, 2008). Critical temperature is the temperature at which the 
animal would soon perish if not quickly removed to a lower temperature. However, critical temperatures are almost never reached in streams with intact riparian overstory within the range of $D$. copei. For example, average daily maximum temperatures ranged from 9.6 to $17.4^{\circ} \mathrm{C}$ in streams on the western Olympic Peninsula (Pollock et al. 2009). In contrast, timber harvest and overstory removal in riparian areas, and the total amount of riparian timber harvest in a given basin can affect stream temperature variability (Beschta et al. 1987, Moore et al. 2005, Pollock et al. 2009). Few studies show water temperature differences between $D$. copei and D. tenebrosus, although Steele et al. (2002) reports the average temperature was lower $\left(9.4^{\circ} \mathrm{C}\right)$ in streams where D. cope $i$ was detected compared to the average temperature $\left(10.3^{\circ} \mathrm{C}\right)$ where $D$. tenebrosus was detected in several streams in Skamania County, Washington. Wagner (2014) found that D. tenebrosus was stressed in cool water at $1.7^{\circ} \mathrm{C}$ while $D$. copei was not, and both species were similarly stressed in warm water at $25.0^{\circ} \mathrm{C}$. Additionally, during systematic spotlight surveys in low flow periods in the summers of 1997 to 2001 at 22 streams in the Willapa Hills, Cascades, and Olympics, in streams with D. copei, temperatures ranged from $7.5-13.0^{\circ} \mathrm{C}$, and averaged $10.9^{\circ} \mathrm{C} ; \mathrm{sd}=1.28$ (L. L. C. Jones, unpublished data). Given that the range of $D$. copei is much more limited than $D$. tenebrosus, water temperature may play a role in its distribution. In general, D. copei is a species associated with cold waters thus elevated or more variable stream temperatures can affect life-history characteristics such as growth rates, movement, and egg incubation, with unknown effects on populations across its range.

\section{Climate Change}

Climate change is adversely affecting amphibian species worldwide, and although related research for species endemic to the Pacific Northwest is deficient, climate change may be the biggest future challenge to the persistence of amphibian species (Blaustein and Wake 1990, Corn 2005). Among areas of the world that support salamanders, western North America (including the Pacific Northwest), together with northern Central America and southern and south-eastern Europe, are regions projected to be most heavily affected by climate change (Hof et al. 2011). Effects on amphibians from climate change can be either direct (e.g. increased temperature variability or extreme weather patterns), or indirect such as food availability, predation, life-history changes, and disease (Blaustein et al. 2010). For the Pacific Northwest, regional climate models project rates of warming of 0.1 to $0.6^{\circ} \mathrm{C}$ per decade, with precipitation trends tending toward wetter autumns and winters but drier summers (Mote and Salathe 2010), which may affect the D. copei distribution and life history.

In Olympic National Park, D. copei had the narrowest distribution as compared to Olympic Torrent Salamanders, Rhyacotriton olympicus (Gaige, 1917), and Coastal Tailed Frogs, and also had the strongest relationship to climate variables of the three species (Adams and Bury 2002). Among these 
species, D. copei had a strong positive association with precipitation, suggesting that an aquatic-obligate life history may increase reliance on streams with permanent flow thus affecting its range and dispersal capabilities. This is problematic because trends in annual stream flow in the Pacific Northwest show strong and significant declines at most gauging stations-in essence, the driest 25\% of years (1948-2006) are becoming substantially drier (Luce and Holden 2009); and late-summer base-flow recession is becoming more pronounced (Sawaske et al. 2014). These factors may affect the species' future distribution. For example, in assessing landscape and climatic factors that restrict gene flow, Trumbo et al. (2013) suggested that with the projected patterns of climate change in the Pacific Northwest, habitats will become less suitable for D. copei, and range retractions are likely, particularly in the southern Washington Cascade ecoregion.

\section{Forest Fires}

The effects from forest fires on D. copei and other Dicamptodon salamanders are relatively unstudied. Within the range of $D$. copei, frequencies of large stand-replacing fires are quite different between the Coastal and Cascade ecoregions, with return intervals ranging from centuries along the Olympic coast to decades in lowland Douglas-fir forests of the Cascades ecoregion (Agee 1993). Concerning fire effects that may be relative to Dicamptodon salamanders, Pilliod et al. (2003) found that: 1) stand-replacement fire is a catastrophic disturbance to flora and fauna with subsequent changes in microclimate and stream temperatures; 2) post-fire fine sediment inputs to streams can be greatly increased; and 3) increased peak flows may result from loss of vegetation in the upland forest surrounding streams, causing channel scour. Post-fire landslides and debris flow events could sluice streams, killing salamanders within the stream prism, and may occur after stand-replacing fires or some timber management activities on unstable slopes. In contrast, lowintensity fires, including prescribed fire for fuels reduction treatments in forested uplands, may have little adverse effect on this species. However, increased fire frequency potentially exacerbated by climate change may be a concern for $D$. copei populations particularly in the southern Cascade ecoregion.

\section{Habitat Fragmentation}

As described previously, the patchy distribution of $D$. copei suggests that landscape, climatic, and glacial factors have all contributed to natural fragmentation. The species' constrained dispersal capability also plays a part in the degree to which adjacent populations may be connected (Steele 2006, Steele and Storfer 2007). Anthropogenic disturbances such as roads and habitat fragmentation from timber management and related disturbances have likely contributed to the level of fragmentation across the species range. Loss of current connectivity among habitat patches may be a concern for further 
population isolation. Trumbo et al. (2013) suggested that, within the species range, fragmentation and isolation from logging would continue, exacerbated by the effects of climate change, but that connectivity could be retained by maintaining and improving river and stream dispersal corridors, with conservation of the remaining high-quality habitats.

\section{Diseases}

The amphibian chytrid fungus, Batrachochytrium dendrobatidis (Longcore et al. 1999), herein abbreviated Bd, has recently been detected in Oregon and Washington (http://www.bd-maps.net/). This disease is particularly notable relative to $D$. copei because of its predominantly aquatic life history. Bd is an aquatic fungus and has been found in greater levels in aquatic amphibians, and more often in older larvae and metamorphosed animals due to higher keratin content of their skin, upon which Bd relies. Some amphibian species can be carriers of $\mathrm{Bd}$, and do not show symptoms of the disease. Although this is not fully understood, they may be resistant to the disease, or the intensity of infection Bd or strain virulence may be low. Hossack et al. (2010) reported no $\mathrm{Bd}$ on $60 \mathrm{D}$. tenebrosus larvae from California, yet they found it on three metamorphosed Idaho Giant Salamanders from Idaho and Montana, and on one of 57 Idaho Giant larvae. As far as we have been able to determine, no studies have tested for $\mathrm{Bd}$ in $D$. copei or D. tenebrosus in Oregon or Washington (http://www.bd-maps.net/isolates/; accessed May 2013). In general, prevalence appears to be low among Pacific Northwest amphibians associated with small streams, but only one study, Hossack et al. (2010), has targeted headwater amphibians. A newly discovered chytrid fungus, B. salamandrivorans (Martel et al. 2013) has been recently found to be highly infective to a broad group of salamanders, with high incidence of mortality for many taxa from across the world (Martel et al. 2014). This fungus appears to have an Asian origin, with a recent introduction to Europe where it is killing salamanders. At this time, we do not know if Dicamptodon are vulnerable to this fungus, and it is presumed not to occur in North America, however, monitoring is warranted due to the lethal effects on many taxa.

Vulnerability of $D$. copei to other pathogens has not been studied, yet parasites such Oligochaetes have been found in feces and spermatophores of $D$. tenebrosus and Trichodina has been found in blood samples of both species (Wagner 2014). Ranavirus is another emerging infectious disease tied to massive mortality episodes in a variety of amphibian species, but has not yet been detected in Dicamptodon salamanders.

\section{Introduced Species}

Dicamptodon copei larvae are likely prey for non-native Eastern Brook Trout, Salvelinus fontinalis. First introduced in the early 1900s, Brook Trout are widely distributed in many high mountain lakes and headwater streams and co- 
exist with $D$. copei in many areas across the salamander's range. The magnitude of this potential threat to D. cope $i$ in Oregon and Washington is not well known. The amphibian chytrid fungus and Ranavirus mentioned previously are also considered introduced species.

\section{Management considerations for conservation of the species}

An overarching conservation goal for Dicamptodon copei is to contribute to a reasonable likelihood of long-term persistence within its range in Washington and Oregon. Achievement of this goal involves assessment and prioritization of the species' occurrence and geographic range relative to species management needs.

Although recommendations can be developed for the entire range of the species, the variety of site conditions, historical and ongoing site-specific impacts, and population-specific issues warrant consideration of each site with regard to the extent of both habitat protection and possible restoration measures. General known threats are listed above, and should be considered during development of site-level and basin-level management approaches.

\section{Specific Considerations}

At locations where Cope's Giant Salamanders have been found:

01) Retain streamside riparian buffer zones to: A) reduce streambank erosion and intercept fine sedimentation before reaching stream channels because in-channel coarse substrates are important to the life histories of giant salamanders; B) retain stream shading to reduce alteration of stream temperatures; and C) reduce peak flow variability from runoff. Site conditions (aspect, hill- shading, vegetation condition, watershed condition, cumulative effects) warrant consideration when buffer widths are considered and whether managed buffers or no-entry buffers are needed.

02) Employ variable-retention timber harvest such as commercial thinning or aggregated green-tree retention in adjacent riparian or upland forests to retain canopy closure and ameliorate microclimate shifts or erosion in the riparian zones and streams. Restoration of riparian forests to accelerate oldforest conditions and structures, such as future recruitment of large down wood may provide long-term benefits to this species and the larger community in streams and riparian areas, and should be considered on a case-by-case basis, weighing short-term costs with longer-term benefits.

03) Manage road construction, repair, and maintenance to accommodate both up- and downstream passage for terrestrial and aquatic amphibians like $D$. copei. However, consideration of invasive species passage is also needed, 
so as not to inadvertently introduce non-native predators or other types of species with potential adverse effects on salamanders into upstream reaches.

04) Manage forest stands to reduce the likelihood of stand-replacement fires, including thinning of young, dense stands.

05) Closely monitor and/or restrict chemical applications near stream channels.

06) Restrict soil-compacting equipment or vehicle refueling near stream channels.

07) Reduce the likelihood of non-native predators such as Brook Trout in streams.

08) Assess the short- vs. long-term impact and the spatial scale of the impact of a proposed activity to identify the potential hazards specific to the persistence of the salamander.

09) The hazards to and exposure of salamanders of some activities relative to substrate disturbance, microclimate shifts, and incidental mortality should be minimized. A minimal or short-term risk may be inappropriate for a small, isolated population, whereas it may be possible in part of a large occupied habitat. Thus, both current and predicted future conditions of the site and its habitat can be considered during risk assessment procedures. If the risk, hazards, or exposure to actions are unknown or cannot be assessed, conservative measures are recommended.

10) Disinfect field gear between sites to reduce movement of pathogens. Disinfection guidelines to reduce risk of transmission of $\mathrm{Bd}$ and other aquatic invasive species are available at: http://www.fs.usda.gov/detail/r4/landmanagement/resourcemanagement/?ci $\mathrm{d}=$ stelprdb5373570

11) Disinfect water that is transported away from occupied stream reaches, or brought in from elsewhere (e.g. for fire management; see web link, http://www.fs.usda.gov/detail/r4/landmanagement/resourcemanagement/?ci $\mathrm{d}=$ stelprdb5373570).

12) Delineate the spatial extent of the area occupied by this species for future monitoring. Site survey information should be compared to existing site data to document possible range extensions or retractions. 
13) Genetic analyses have suggested that overland movements are restricted for this species. However, we do not know the extent to which this animal may disperse overland; hence it is prudent to consider management activities (e.g. increase forest canopy retention, logging systems requiring minimal roads) to promote connectivity among stream and riparian habitats, especially watersheds with no aquatic connectivity.

14) Since we know little about overland dispersal for this species, circumstances may warrant minimizing habitat fragmentation by retaining undisturbed areas extending from occupied stream reaches into uplands. For example, riparian habitat features such as seeps or wetlands likely benefit dispersal and persistence of terrestrial and aquatic amphibians like D. copei across landscapes; these features should be identified (Janisch et al. 2011). Thus, buffer or riparian reserve boundaries should be extended from occupied streams to encompass and protect these features.

15) Consider hill-shading and aspect in management of connectivity habitats; for example, such that naturally exposed areas prone to higher temperatures have vegetative buffering (canopy retention). Such considerations are especially important relative to potential future effects of climate change.

16) Restore disturbed sites to more closely mimic naturally occurring habitats occupied by the species, taking into account life history needs, such as perennial water with plunge-pool channel features with boulder and cobble substrates.

17) Protect water temperature buffering. For example, D. copei occur in some streams that have a more-or-less constant temperature from a spring source. Altering the water source and flow patterns (e.g. through a diversion) could affect the temperature minimum, maximum, and fluctuations.

\section{Further Research}

A priority need is to gain a more precise rendering of the current distribution of D. copei in Oregon and Washington. Other information gaps include many aspects of the basic life history and habitat associations of the species, and effects of various disturbances including disease and climate change. Since amphibian dispersal and persistence depend part on the speed and regularity with which the climate pattern advances (Early and Sax 2011); climate envelope modeling may provide insight into future shifts in the species range. More information is needed on the prevalence and consequence of pathogens including the amphibian chytrid fungus, $\mathrm{Bd}$, in this species. Several gaps relative to site and watershed management remain. In particular, how well do riparian buffers protect this species (what riparian management options 
should be considered, how wide should buffers be)? Do we need to consider upland management activities to address population connectivity? What are the movement patterns of this species? To what extent are road crossings affecting dispersal across the species' range? What are some adequate culvert design criteria to insure that road crossing barriers are minimized?

With regard to life history and population ecology, how will projected reductions in stream flow and increases in water temperature, like those attributed to climate change scenarios, affect the animal's life history, movements, physiology, and metamorphosis? To what effect do non-native species like Brook Trout influence salamander populations and what are the interspecific interactions with native trout? What is the spatial extent of a stable population, or rather the range of areas for population persistence? At what abundances are these animals found in Oregon and Washington? Lastly, the ecological role of this species in the larger ecosystem is poorly understood. What is their place in the trophic structure of the ecosystem? Are they key prey (or predator) in trophic cascades? Are food webs altered by forest management practices?

The data gaps discussed above each relate to needed research on this animal. In particular, there is little information on how various contemporary forest management practices such as how riparian buffers may affect microhabitats or populations of these salamanders. Stream-crossing culverts and design specifications have been little studied relative to this species. Also, the effects of climate change on habitats and the spread of $\mathrm{Bd}$ and other pathogens in this species are poorly known. Climate envelope modeling would allow projections of effects within Oregon and Washington, and may prioritize habitats for management or conservation.

\section{Conclusions}

Our compendium of biological knowledge and management considerations for the Cope's Giant Salamander provides renewed understanding to integrate into conservation and status assessments. Recent surveys documenting the patchy distribution of this species, along with genetic results that suggest the species to be dispersal-limited, support site-specific management considerations. However, designing habitat connectivity pathways for a largely aquatic life-form distributed across discrete watersheds with no freshwater linkages may be a conservation challenge. Research might examine genetic connectivity patterns across more mesic (i.e., near-coastal) landscapes that could serve as selective gene-flow zones if terrestrial forms are more frequent there. Upland forest management for improving dispersal has been a consideration for other endemic stream-breeding amphibians in the Pacific Northwest (Spear et al. 2011; Olson and Burnett 2009, 2013) and those concepts might be applicable for this species. However, minimizing distances overland might be a key consideration for planning connectivity pathways. 


\section{Acknowledgments}

We thank the many people who provided site locality data and several others who also provided biological information including R. Bruce Bury, Char Corkran, Alan Dyck, Jerry Freilich, Marc Hayes, Roger Hoffman, Scott Horton, Danni Kline, Chris Knauf, Bill Leonard, Barbara Samora, Andrew Storfer and Dave Vesley. Kelly Christiansen created the maps. Lisa Wagner, Betsy Howell and Kathryn Ronnenberg provided helpful reviews and comments.

\section{Literature Cited}

Adams, M. J. and R. B. Bury. 2002. The endemic headwater stream amphibians of the American Northwest: associations with environmental gradients in a large forested preserve. Global Ecology and Biogeography 11:169-178. http://dx.doi.org/10.1046/j.1466-822X.2002.00272.x

Agee, J. K. 1993. Fire Ecology of Pacific Northwest Forests. Island Press. Washington, District of Columbia, USA. 493 pp.

Andrews, K. M., J. W. Gibbons, and D. M. Jochimsen. 2008. Ecological effects of roads on amphibians and reptiles: a literature review. pp. 121-143. In, Mitchell, J. C., R. E. Jung Brown, B. Bartholomew (Editors). Chapter 9. Herpetological Conservation, Volume 3. Urban Herpetology. Society for the Study of Amphibians and Reptiles. Salt Lake City, Utah, USA. 608 pp.

Antonelli, A. L., R. A. Nussbaum, and S. D. Smith. 1972. Comparative food habits of four species of stream-dwelling vertebrates (Dicamptodon ensatus, D. copei, Cottus tenuis, Salmo gairdneri). Northwest Science 46:277-289.

Ashton, D. T., S. B. Marks, and H. H Welsh, Jr. 2006. Evidence of continued effects from timber harvesting on lotic amphibians in redwood forests of northwestern California. Forest Ecology and Management 221:83-193. http://dx.doi.org/10.1016/j.foreco.2005.09.015

Beschta, R. L. 1978. Long-term patterns of sediment production following road construction and logging in the Oregon Coast Range. Water Resources Research 14(6):1011-1016. http://dx.doi.org/10.1029/WR014i006p01011

Beschta, R. L, R. E. Bilby, G. W. Brown, L. B. Holtby, and T. D. Hofstra. 1987. Stream temperature and aquatic habitat: Fisheries and forestry interactions. pp. 191-232. In, Salo, E. and T. Cundy (Editors). Streamside Management: Forestry and Fisheries Interactions. Institute of Forest Resources Contribution 57. University of Washington, Seattle, Washington, USA. 471 pp.

Biek, R., L. S. Mills, and R. B. Bury. 2002. Terrestrial and stream amphibians across clearcut-forest interfaces in the Siskiyou Mountains, Oregon. Northwest Science 76(2): 129-140.

Bisson, P. A., M. G. Raphael, A. D. Foster, and L. L. C. Jones. 2002. Influence of site and landscape features on vertebrate assemblages in small streams. pp. 61-72. In, Johnson, A. C., R. W. Haynes and R. A. Monserud (Editors). Congruent Management of Multiple Resources: Proceedings from the Wood Compatibility Initiative Workshop. General Technical Report PNW-GTR-563. U. S. Department of Agriculture, Forest Service, Pacific Northwest Research Station. Portland, Oregon, USA. 252 pp.

Blaustein, A. R. and D. B. Wake. 1990. Declining amphibian populations: A global phenomenon? Trends in Ecology and Evolution 5:203-204. http://dx.doi.org/10.1016/0169-5347(90)90129-2

Blaustein, A. R., S. C. Walls, B. A. Bancroft, J. J. Lawler, C. L. Searle, and S. S. Gervasi. 2010. Direct and indirect effects of climate change on amphibian populations. Diversity 2:281-313. http://dx.doi.org/10.3390/d2020281

Brinkman, J. N., S. K. Sessions, A. Houben, and D. M. Green. 2000. Structure and evolution of supernumerary chromosomes in the Pacific Giant Salamander, Dicamptodon tenebrosus. Chromosome Research 8:477-485. http://dx.doi.org/10.1023/A:1009215621509

Bury, R. B. 1983. Differences in amphibian populations in logged and old growth redwood forests. Northwest Science 57:167-178.

Bury, R. B. 2008. Low thermal tolerances of stream amphibians in the Pacific Northwest: implications for riparian and forest management. Applied Herpetology 5:63-74. http://dx.doi.org/10.1163/157075408783489211

Bury, R. B., P. S. Corn, K. B. Aubry, F. F. Gilbert, and L. L. C. Jones. 1991. Aquatic amphibian communities in Oregon and Washington. pp. 353-362. In, Ruggiero, L. F., K. B. Aubry, A. B. 
Carey, and M. H. Huff (Editors). Wildlife and Vegetation of Unmanaged Douglas-fir Forests. General Technical Report PNW-GTR-285. U. S. Department of Agriculture, Forest Service, Pacific Northwest Research Station. Portland, Oregon, USA. 533 pp.

Bury, R. B., R. Demmer, and J. Sippel. 2014. Discovery of Cope's Giant Salamanders (Dicamptodon copei) East of the Oregon Cascade Range Crest. Northwestern Naturalist 95:115-119.

Collins, J. P. 2010. Amphibian decline and extinction: What we know and what we need to learn. Diseases of Aquatic Organisms 92:93-99. http://dx.doi.org/10.3354/dao02307

Corkran, C. C. and C. Thoms. 2006. Amphibians of Oregon, Washington and British Columbia: A Field Identification Guide. Lone Pine Publishing, Edmonton, Alberta, and Vancouver, British Columbia, Canada and Auburn, Washington, USA. 176 pp.

Corn, P. S. 2005. Climate change and amphibians. Animal Biodiversity and Conservation 28.1:5967.

Corn, P. S., and R. B. Bury. 1989. Logging in western Oregon: Responses of headwater habitats and stream amphibians. Forest Ecology and Management 29:39-57. http://dx.doi.org/10.1016/0378-1127(89)90055-8

Cover, M. R., J. A. de la Fuente, and V. H. Resh. 2010. Catastrophic disturbances in headwater streams: the long-term ecological effects of debris flows and debris floods in the Klamath Mountains, northern California. Canadian Journal of Fisheries and Aquatic Sciences 67:15961610. http://dx.doi.org/10.1139/F10-079

Crisafulli, C. M., L. S. Trippe, C. P. Hawkins, J. A. MacMahon. 2005. Amphibian response to the 1980 eruption of Mount St. Helens. pp 183-197. In, Dale, V. H., F. J. Swanson, and C. M. Crisafulli (Editors). Ecological Responses to the 1980 Eruption of Mount St. Helens. SpringerVerlag. New York, New York, USA. 342 pp. http://dx.doi.org/10.1007/0-387-28150-9 13

Cudmore, W. W., and R. B. Bury. 2014. Resource partitioning in two stream salamanders, Dicamptodon tenebrosus and Rhyacotriton cascadae, in the Cascade Mountains, Oregon. American Midland Naturalist 172:191-199. http://dx.doi.org/10.1674/0003-0031-172.1.191

Curtis, J. M. R. and E. B. Taylor. 2003. The genetic structure of Coastal Giant Salamanders (Dicamptodon tenebrosus) in a managed forest. Biological Conservation 115:45-54. http://dx.doi.org/10.1016/S0006-3207(03)00092-2

Daugherty, C. H., F. W. Allendorf, W. W. Dunlap, and K. L. Knudsen. 1983. Systematic variations of geographic patterns of genetic variation in the genus Dicamptodon. Copeia 3:679-691. http://dx.doi.org/10.2307/1444332

deMaynadier, P. G. and M. L. Hunter Jr. 2000. Road effects on amphibian movements in a forested landscape. Natural Areas Journal 35:217-225.

Dudaniec, R. Y., S. F. Spear, J. S. Richardson and A. Storfer. 2012. Current and historical drivers of landscape genetic structure in core and peripheral salamander populations. PLOS ONE 7(5):112. http://dx.doi.org/10.1371/journal.pone.0036769

Early, R. and D. F. Sax. 2011. Analysis of climate paths reveals potential limitations on species range shifts. Ecology Letters 14:1125-1133. http://dx.doi.org/10.1111/j.1461$\underline{0248.2011 .01681 . x}$

Esselstyn, J. A. and R. C. Wildman. 1997. Observations of Juga in diet of larval giant salamanders (Dicamptodon tenebrosus). Northwestern Naturalist 78(2):70-73. http://dx.doi.org/10.2307/3536849

Fedorenkova, A., J. A. Vonk, H. J. R. Lenders, R. C. M. Creemers, A. M. Breure, A. J. Hendriks. 2012. Ranking ecological risks of multiple chemical stressors on amphibians. Environmental Toxicology and Chemistry 31(6):1416-1421. http://dx.doi.org/10.1002/etc.1831

Fellers, G. M., S. R. Kuchta. 2005. California Giant Salamander: Dicamptodon ensatus Eschscholtz. pp. 50-53. In, Jones, L. L. C., W. P. Leonard, and D. H. Olson (Editors). Amphibians of the Pacific Northwest. Seattle Audubon Society. Seattle, Washington, USA. 227 pp.

Feral, D, M., A. Camann, and H. H. Welsh Jr. 2005. Dicamptodon tenebrosus larvae within hyporheic zones of intermittent streams in California. Herpetological Review 36(1):26-27.

Foster, A. D. and D. H. Olson. 2014. Conservation assessment for the Cope's Giant Salamander (Dicamptodon copei), Version 1.0. USDA Forest Service, Region 6, and Oregon BLM (Bureau of Land Management). Special Status Species Program. 57 pp. 
General Accounting Office [GAO]. 2001. Land Management Agencies-Restoring fish passage through culverts on Forest Service and BLM lands in Oregon and Washington could take decades: Report to the ranking minority member, Subcommittee on Interior and related agencies, Committee on Appropriations, House of Representatives. GA0-02-136, 29 pp. (Also available at http://www.gao.gov/new. itemsld02136.pdf)

Gomez, D. M. and R. D. Anthony. 1996. Amphibian and reptile abundance in riparian and upslope areas of five forest types in western Oregon. Northwest Science 70:109-119.

Good, D. A. 1989. Hybridization and cryptic species in Dicamptodon (Caudata: Dicamptodontidae). Evolution 43(4):728-744. http://dx.doi.org/10.2307/2409302

Graff, P. 2006. Riparian vegetation and larval Pacific Giant (Dicamptodon tenebrosus) and adult Western Redback (Plethodon vehiculum) Salamanders in the Oregon Coast Range. M. Sc. Thesis. Oregon State University. Corvallis, Oregon, USA. 123 pp.

Hammerson, G. 2004. Dicamptodon copei. In, IUCN 2014. IUCN Red List of Threatened Species. Version 2014.1. www.iucnredlist.org. (Accessed June 2014).

Hof, C., M. B. Araujo, W. Jetz, C. Rahbek. 2011. Additive threats from pathogens, climate and landuse change for global amphibian diversity. Nature 480(22/29):516-521.

Hoffman, R. L. and J. B. Dunham. 2007. Fish movement ecology in high gradient headwater streams: its relevance to fish passage restoration through stream culvert barriers. U. S. Geological Survey Open-File Report 2007-1140. 40 pp.

Hoffman, R. L., J. B. Dunham, and B. P. Hansen (Editors). 2012. Aquatic organism passage at roadstream crossings-synthesis and guidelines for effectiveness monitoring. U. S. Geological Survey Open-File Report 2012-1090. 64 pp.

Hossack, B. R., M. J. Adams, E. H.Campbell-Grant, C. A. Pearl, J. B. Bettaso, W. J. Barichivich, W. H. Lowe, K. True, J. L.Ware, and P. S. Corn. 2010. Low prevalence of chytrid fungus (Batrachochytrium dendrobatidis) in amphibians of U.S. headwater streams. Journal of Herpetology 44:253-260. http://dx.doi.org/10.1670/09-058.1

Jackson, S. D. 2004. Design and construction of aquatic organism passage at road-stream crossings: ecological considerations in the design of river and stream crossings. pp 20-29. In, Irwin, C. L., P. Garrett, and K. P. McDermott (Editors). Proceedings of the 2003 International Conference on Ecology and Transportation. Center for Transportation and the Environment, North Carolina State University, Raleigh, North Carolina, USA. 688 pp. Available at: http://www.icoet.net/downloads/03ICOETProceedings.pdf (accessed 15 December 2014)

Janisch, J. E., A. D. Foster, and W. J. Ehinger. 2011. Characteristics of small headwater wetlands in second growth forests of Washington, USA. Forest Ecology and Management 261:1265-1274. http://dx.doi.org/10.1016/j.foreco.2011.01.005

Johnston, B. 1998. Terrestrial Pacific Giant Salamanders (Dicamptodon tenebrosus Good) Natural history and their response to forest practices. M. Sc. Thesis. University of British Columbia. Vancouver, British Columbia, Canada. 98 pp.

Johnston, B. and L. Frid. 2002. Clear-cut logging restricts the movements of terrestrial Pacific Giant Salamanders (Dicamptodon tenebrosus Good). Canadian Journal of Zoology 80:2170-2177. http://dx.doi.org/10.1139/z02-213

Jones, L. L. C. and R. B. Bury. 2005. Cope's Giant Salamander Dicamptodon copei Nussbaum. Pp. 46-49. In, Jones, L. L. C., W. P. Leonard, and D. H. Olson (Editors). Amphibians of the Pacific Northwest. Seattle Audubon Society. Seattle, Washington, USA. 227 pp.

Jones, L. L. C., R. B. Bury, and P. S. Corn. 1990. Field observation on the development of a clutch of Pacific giant salamander (Dicamptodon tenebrosus) eggs. Northwestern Naturalist 71:9394. http://dx.doi.org/10.2307/3536778

Jones, L. L. C. and P. S. Corn. 1989. Third specimen of a metamorphosed Cope's Giant Salamander (Dicamptodon copei). Northwestern Naturalist 70(2):37-38.

Jones, L. L. C. and M. G. Raphael. 2001. An interim training guide to differentiate larviform and metamorphosing Cope's Giant (Dicamptodon copei) from Coastal Giant (D. tenebrosus) Salamanders within their range of sympatry. [PowerPoint slides]. Available from U.S. Forest Service, Pacific Northwest Research Station, Olympia, Washington, USA. 
Karwan, D. L., J. A. Gravelle, and J. A. Hubbart. 2007. Effects of timber harvest on suspended sediment loads in Mica Creek, Idaho. Forest Science 53:181-188.

Keith, D. A., M. Mahony, H. Hines, J. Elith, T. J. Regan, J. B. Baumgartner, D. Hunter, G. W. Heard, N. J. Mitchell, K. M. Parris, T. Penman, B. Scheel, C. C. Simpson, R. Tingley, C. R. Tracy, T. M. West, and H. R. Akcakaya. 2014. Detecting extinction risk from climate change by IUCN Red List criteria. Conservation Biology 28:810-819. http://dx.doi.org/10.1111/cobi.12234

Kluber, M. R., D. H. Olson, and K. J. Puettmann. 2008. Amphibian distributions in riparian and upslope areas and their habitat associations on managed forest landscapes of the Oregon Coast Range. Forest Ecology and Management 256:529-535. http://dx.doi.org/10.1016/j.foreco.2008.04.043

Lannoo, M. J. (editor). 2005. Amphibian Declines: The Conservation Status of United States Species. University of California Press. Berkeley, California, USA. 1094 pp. http://dx.doi.org/10.1525/california/9780520235922.001.0001

Leuthold, N., M. J. Adams, and J. P. Hayes. 2012. Short-term response of Dicamptodon tenebrosus larvae to timber management in Southwestern Oregon. Journal of Wildlife Management 76(1):28-37. http://dx.doi.org/10.1002/jwmg.269

Loafman, P. and L. L. C. Jones. 1996. Dicamptodon copei (Cope's Giant Salamander). Metamorphosis and predation. Herpetological Review 27:136.

Luce, C. H. and Z. A. Holden. 2009. Declining annual streamflow distributions in the Pacific Northwest United States, 1948-2006. Geophysical Research Letters 36: L16401, http://dx.doi.org/10.1029/2009GL039407

Marsh, D. M., G. S. Milam, N. P. Gorham, and N. G. Beckman. 2005. Forest roads as partial barriers to terrestrial salamander movement. Conservation Biology 19(6):2004-2008. http://dx.doi.org/10.1111/j.1523-1739.2005.00238.x

Martel, A., M. Blooi, C. Adriaensen, P. Van Rooij, W. Beukema, M. C. Fisher, R. A. Farrer, B. R. Schmidt, U. Tobler, K. Goka, K. R. Lips, C. Muletz, K.R. Zamudio, J. Bosch, S. Lötters, E. Wombwell, T. W. J. Garner, A. A. Cunningham, A. Spitzen-van der Sluijs, S. Salvidio, R. Ducatelle, K. Nishikawa, T. T. Nguyen, J. E. Kolby, I. Van Bocxlaer, F. Bossuyt, and F. Pasmans. 2014. Recent introduction of a chytrid fungus endangers Western Palearctic salamanders. Science 346:630-631. http://dx.doi.org/10.1126/science.1258268

Martel, A., A. Spitzen-van der Sluijs, M. Blooi, W. Bert. R. Ducatelle, M. C. Fisher, A. Woeltjes, W. Bosman, K. Chiers, F. Bossuyt, and F. Pasmans. 2013. Batrachochytrium salamanderivorans sp. nov. causes lethal chytridiomycosis in amphibians. Proceedings of the National Academy of Sciences of the United States of America 110:15325-15329. http://dx.doi.org/10.1073/pnas.1307356110

McComb, W. C., C. L. Chambers, and D. M. Newton. 1993a. Small mammal and amphibian communities and habitat associations in red alder stands, central Oregon Coast Range. Northwest Science 67:181-188.

McComb, W. C., K. McGarigal, and R. G. Anthony. 1993b. Small mammal and amphibian abundance in streamside and upslope habitats of mature Douglas-fir stands, western Oregon. Northwest Science 67(1):7-15.

Moore, R. D., D. L. Spittlehouse, and A. Story. 2005. Riparian microclimate and stream temperature response to forest harvesting: A review. Journal of American Water Resources Association 41:813-834. http://dx.doi.org/10.1111/j.1752-1688.2005.tb04465.x

Mote, P., E. Salathe. 2010. Future climate in the Pacific Northwest. Climatic Change 102:29-50. http://dx.doi.org/10.1007/s10584-010-9848-z

Nussbaum, R. A. 1969. Nests and eggs of the Pacific Giant Salamander, Dicamptodon ensatus (Eschscholtz). Herpetologica 25(4):257-262.

Nussbaum, R. A. 1970. Dicamptodon copei, n. sp., from the Pacific Northwest, U.S.A. (Amphibia: Caudata: Ambystomatidae). Copeia 3:506-514. http://dx.doi.org/10.2307/1442278

Nussbaum, R. A. 1976. Geographic variation and systematics of salamanders of the genus Dicamptodon (Strauch) (Ambystomatidae). Miscellaneous Publications No. 149. Museum of Zoology, University of Michigan. Ann Arbor, Michigan, USA. 94 pp. 
Nussbaum, R. A., E. D. Brodie Jr., and R. M. Storm. 1983. Amphibians and reptiles of the Pacific Northwest. University Press of Idaho. Moscow, Idaho, USA. 332 pp.

Nussbaum, R. A. and G. W. Clothier. 1973. Population structure, growth, and size of larval Dicamptodon ensatus (Eschscholtz). Northwest Science 47(4):218-227.

Olson, D. H. and K. M. Burnett. 2009. Design and management of linkage areas across headwater drainages to conserve biodiversity in forest ecosystems. Forest Ecology and Management 258: 117-126. http://dx.doi.org/10.1016/j.foreco.2009.04.018

Olson, D. H. and K. M. Burnett. 2013. Geometry of forest landscape connectivity: Pathways for persistence. pp. 220-238. In, P. D. Anderson and K. L. Ronnenberg (Editors). Density Management in the 21st Century: West Side Story. General Technical Report PNW-GTR-880. U. S. Department of Agriculture, Forest Service, Pacific Northwest Research Station. Portland, Oregon, USA. $241 \mathrm{pp}$.

Olson, D. H. and J. I. Burton. 2014. Near-term effects of repeated-thinning with riparian buffers on headwater stream vertebrates and habitats in Oregon, USA. Forests 5:2703-2729. http://dx.doi.org/10.3390/f5112703

Olson, D. H. and T. Chestnut. 2014. Trouble in the aquatic world: How wildlife professionals are battling amphibian declines. The Wildlife Professional 8(4):28-31.

Olson, D. H. and C. Rugger. 2007. Preliminary study of the effects of headwater riparian reserves with upslope thinning on stream habitats and amphibians in western Oregon. Forest Science 53(2):331-342.

Olson, D. H. and G. Weaver. 2007. Vertebrate assemblages associated with headwater hydrology in western Oregon managed forests. Forest Science 53:343-355.

Oregon Biodiversity Information Center (ORBIC). 2013. Rare, Threatened and Endangered Species of Oregon. Institute for Natural Resources. Portland State University, Portland, Oregon, USA. $111 \mathrm{pp}$.

Parker, M. S. 1991. Relationship between cover availability and larval Pacific Giant Salamander density. Journal of Herpetology 25(3):355-357. http://dx.doi.org/10.2307/1564597

Parker, M. S. 1994. Feeding ecology of stream-dwelling Pacific Giant Salamander larvae (Dicamptodon tenebrosus). Copeia 3:705-718. http://dx.doi.org/10.2307/1447187

Pilliod, D. S., R. B. Bury, E. J. Hyde, C. A. Pearl, and P. S. Corn. 2003. Fire and amphibians in North America. Forest Ecology and Management 178:163-181. http://dx.doi.org/10.1016/S0378-1127(03)00060-4

Pollock, M. M., T. J. Beechie, M. Liermann, R. E. Bigley. 2009. Stream temperature relationships to forest harvest in western Washington. Journal of the American Water Resources Association 45(1):141-156. http://dx.doi.org/10.1111/j.1752-1688.2008.00266.x

Pollett, K. L., J. G. MacCraken, and J. A. MacMahon. 2010. Stream buffers ameliorate the effects of timber harvest on amphibians in the Cascade Range of southern Washington, USA. Forest Ecology and Management 260:1083-1087. http://dx.doi.org/10.1016/j.foreco.2010.06.035

Price, R. F., D. J. Dugger, T. L. Hicks, and M. P. Hayes. 2006. Dicamptodon copei, Predation. Herpetological Review 37(4):436-437.

Raphael, M. G., P. A. Bisson, L. L. C. Jones, and A. D. Foster. 2002. Effects of streamside forest management on the composition and abundance of stream and riparian fauna of the Olympic Peninsula. pp 27-40. In, A. C. Johnson, R. W. Haynes, and R. A. Monserud (Editors). Congruent Management of Multiple Resources: Proceedings from the Wood Compatibility Initiative Workshop. General Technical Report PNW-GTR-563. U. S. Department of Agriculture, Forest Service, Pacific Northwest Research Station, Portland, Oregon, USA. 252 pp.

Rundio, D. E. 2002. Coexistence of top predators in headwater streams: pathways of intraguild predation between Pacific Giant Salamander larvae and cutthroat trout. M. Sc. Thesis. Oregon State University. Corvallis, Oregon, USA. 96 pp.

Rundio, D. E. and D. H. Olson. 2003. Antipredator defenses of larval Pacific Giant Salamanders (Dicamptodon tenebrosus) against Cutthroat Trout (Oncorhynchus clarki). Copeia 2003(2):392-397. http://dx.doi.org/10.1643/0045-8511(2003)003[0402:ADOLPG]2.0.CO;2 
Ryan, M. E., W. J. Palen, M. J. Adams, and R. M. Rochefort. 2014. Amphibians in the climate vise: loss and restoration of resilience of montane wetland ecosystems in the western US. Frontiers in Ecology and the Environment 12(4): 232-240. http://dx.doi.org/10.1890/130145

Sagar, J. P. 2004. Movement and demography of larval Coastal Giant Salamanders (Dicamptodon tenebrosus) in streams with culverts in the Oregon Coast Range. M. Sc. Thesis. Oregon State University. Corvallis, Oregon, USA. 83 pp.

Sagar, J. P, D. H. Olson, and R. A. Schmitz. 2007. Survival and growth of larval Coastal Giant Salamanders (Dicamptodon tenebrosus) in streams in the Oregon Coast Range. Copeia 2007:123-130. http://dx.doi.org/10.1643/0045-8511(2007)7[123:SAGOLC]2.0.CO;2

Sawaske, S. R. and D. L. Freyberg. 2014. An analysis of trends in baseflow recession and low-flows in rain-dominated coastal streams of the Pacific coast. Journal of Hydrology 519:599-610. http://dx.doi.org/10.1016/j.jhydrol.2014.07.046

Sepulveda, A. J. and W. H. Lowe. 2009. Local and landscape-scale influences on the occurrence and density of Dicamptodon aterrimus, the Idaho Giant Salamander. Journal of Herpetology 43(3):469-484. http://dx.doi.org/10.1670/08-193R2.1

Sheridan, C. D. and D. H. Olson. 2003. Amphibian assemblages in zero-order basins in the Oregon Coast Range. Canadian Journal of Forest Resources 33:1452-1477. http://dx.doi.org/10.1139/x03-038

Silvestri, S. V. and R. G. Douglas. 2006. Dicamptodon tenebrosus defense. Herpetological Review 37(4): 436-437.

Sodhi, N. S., D. Bickford, A. C. Diesmos, T. M. Lee, L. O. Koh, B. W. Brook, C. H. Sekercioglu, and C. J. A. Bradshaw. 2008. Measuring the meltdown: drivers of global amphibian extinction and decline. PLOS ONE 3(2): e1636. http://dx.doi.org/10.1371/journal.pone.0001636

Spear, S. F., J. Baumsteiger, and A. Storfer. 2011. Type N Experimental Buffer Treatment Study: baseline measures of genetic diversity and gene flow of three stream-associated amphibians. Cooperative Monitoring Evaluation and Research Report, CMER 06-605. Washington Department of Natural Resources. Olympia, Washington, USA. 72 pp.

Steele, C. A. 2006. Speciation, phylogeography, and gene flow in giant salamanders (Dicamptodon). $\mathrm{Ph}$. D. Dissertation. Washington State University. Pullman, Washington, USA. $126 \mathrm{pp}$.

Steele, C. A., J. Baumsteiger, and A. Storfer. 2009. Influence of life-history variation on the genetic structure of two sympatric salamander taxa. Molecular Ecology 18:1629-1639. http://dx.doi.org/10.1111/j.1365-294X.2009.04135.x

Steele C. A. and C. Brammer. 2006. Dietary overlap in giant salamanders (Dicamptodon): applying null models to resource partitioning. Western North American Naturalist 66(1):115-120. http://dx.doi.org/10.3398/1527-0904(2006)66[115:DOIGSD]2.0.CO;2

Steele, C. A., E. D. Brodie Jr., and J. G. MacCracken. 2002. Influence of forest age on densities of Cope's and Pacific Giant Salamander. Northwest Science 76:347-352.

Steele, C. A., B. C. Carstens, A. Storfer, and J. Sullivan. 2005. Testing hypotheses of speciation timing in Dicamptodon copei and Dicamptodon aterrimus (Caudata: Dicamptodontidae). Molecular Phylogenetics and 36:90-100. http://dx.doi.org/10.1016/j.ympev.2004.12.001

Steele, C. A. and A. Storfer. 2007. Phylogeographic incongruence of codistributed amphibian species based on small differences in geographic distribution. Molecular Phylogenetics and Evolution 43:468-479. http://dx.doi.org/10.1016/j.ympev.2006.10.010

Stoddard, M. A., J. P. Hayes. 2005. The influence of forest management on headwater stream amphibians at multiple spatial scales. Ecological Applications 15:811-823. http://dx.doi.org/10.1890/03-5195

Strahler, A. N. 1957. Quantitative analysis of watershed geomorphology. Transactions of the American Geophysical Union 38(6):913-920. http://dx.doi.org/10.1029/TR038i006p00913

Stuart, S. N., J. S. Chanson, N. A. Cox, B. E. Young, A. S. L. Rodrigues, D. L. Fischman, and R. W. Waller. 2004. Status and trends of amphibian declines and extinctions worldwide. Science 306:1783-1786. http://dx.doi.org/10.1126/science.1103538

Swanson, F. J., S. L. Johnson, S. V. Gregory, and S. A. Acker. 1998. Flood disturbance in a forested mountain landscape. BioScience 48(9):681-689. http://dx.doi.org/10.2307/1313331 
Trumbo, D. R., S. F. Spear, J. Baumsteiger, and A Storfer. 2013. Range wide landscape genetics of an endemic Pacific Northwestern salamander. Molecular Ecology 16 pp. http://dx.doi.org/10.1111/mec. 12168

Wagner, L. 2014. Life history variables of Dicamptodon salamanders. Ph. D. Dissertation. Oregon State University, Corvallis. USA. 123 pp.

Wake, D. B. and V. T. Vredenburg. 2008. Are we in the midst of the sixth mass extinction? A view from the world of amphibians. Proceedings of the National Academy of Sciences (USA) 105 (Supplement 1):11466-11473. http://dx.doi.org/10.1073/pnas.0801921105

Washington Natural Heritage Program (WHNP). 2013. A partial list of animals in Washington. http://www1.dnr.wa.gov/nhp/refdesk/lists/animal_ranks.html (Accessed September 2014).

Welsh, H.H. Jr. 2005. Coastal Giant Salamander Dicamptodon tenebrosus. Baird and Girard. pp. 5457. In, Jones, L. L. C., W. P. Leonard, and D. H. Olson (Editors). Amphibians of the Pacific Northwest. Seattle Audubon Society, Seattle, Washington, USA. 227 pp.

Welsh, H. H. Jr. and G. R. Hodgson. 2008. Amphibians as metrics of critical biological thresholds in forested headwater streams of the Pacific Northwest, U.S.A. Freshwater Biology 53:14701488. http://dx.doi.org/10.1111/j.1365-2427.2008.01963.x

Wilkins, R .N. and N. P. Peterson. 2000. Factors related to amphibian occurrence and abundance in headwater streams draining second-growth Douglas-fir forests in southwestern Washington. Forest Ecology and Management 139:79-91. http://dx.doi.org/10.1016/S0378-1127(99)003369

World Wildlife Fund. 2014. The Living Planet Report 2014. http://www.worldwildlife.org/pages/living-planet-report-2014 (Accessed 6 October 2014). 